مناقشات مجلس النواب العراقي لميزانية وزارة المعارف

$$
\text { (م) (9\&0-19ro) }
$$

$$
\begin{aligned}
& \text { اعداد } \\
& \text { أحمد صابر عبد العزيز } \\
& \text { طالب دكتور اه - قسم التاريخ } \\
& \text { كلية البنات - جامعة عين شمس اهن }
\end{aligned}
$$

$$
\text { تحث إثر اف }
$$

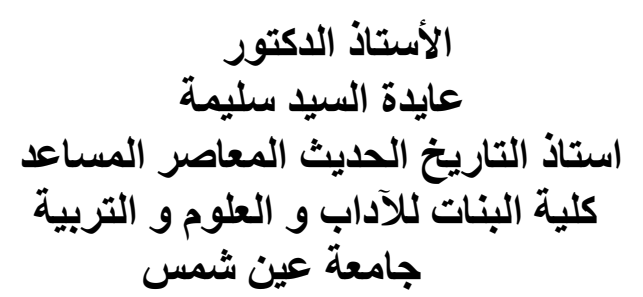

الأستاذ الاكتور

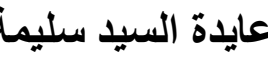

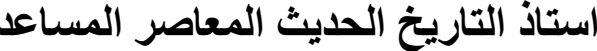

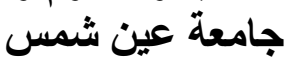

\author{
الأستاذ الاكتور \\ خلف عبد العظيم الميري الأوري

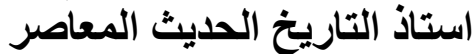 \\ كلية البنات للآداب و العلوم النو و التربية

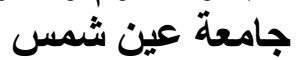

\title{
المــدمـة
}

الحمد لله رب العالمين و الصلاة و السلام على سيدنا محمد النبي الامين صلى الله عليه وسلم،

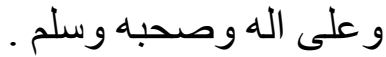
عاش أبناء العراق في المدة التي سبقت تشكيل أول حكومة عام • ب أو برئاسة عبد الرحمن

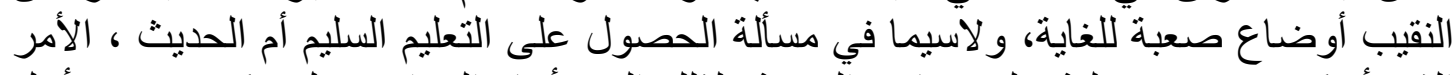

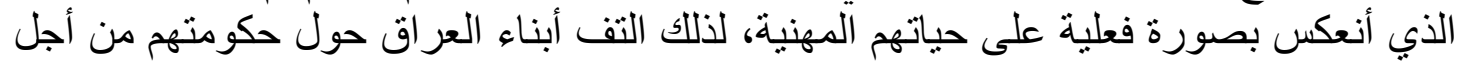
على هذا الأساس بدأت الحكومة لحمة أنشاء عدد من المدارس في ووضع مناهج جديدة ومتطورة

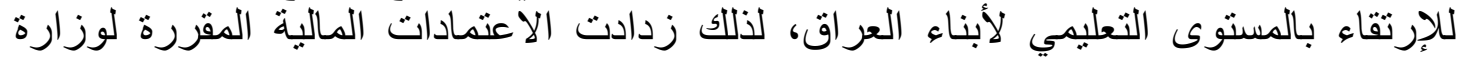


المعارف حتى عام 9 \ (، حيث طالب وقد شهر مجلس النواب العر اقي من مناقشاته خلال هذه

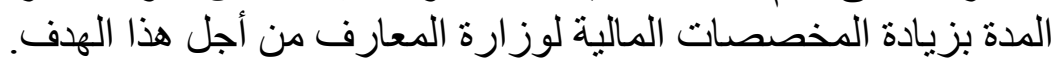

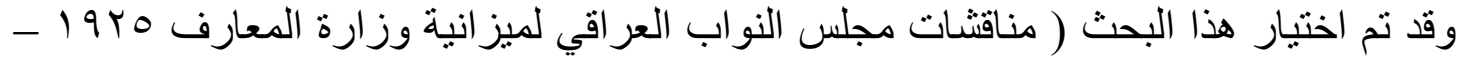

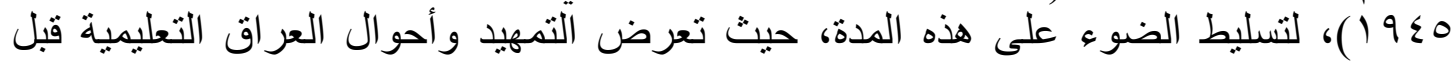

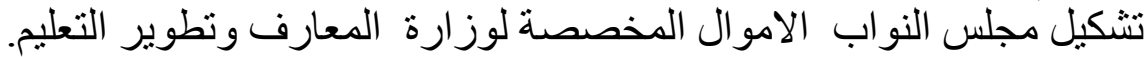

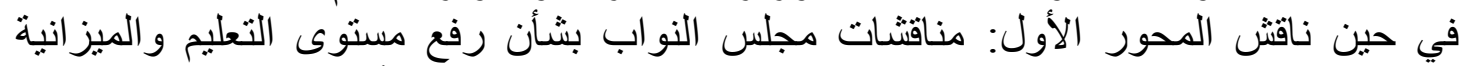

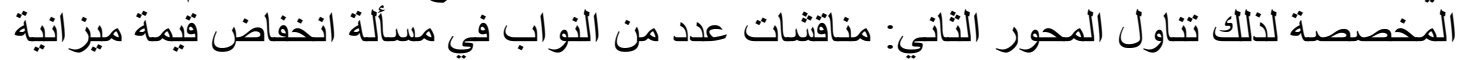

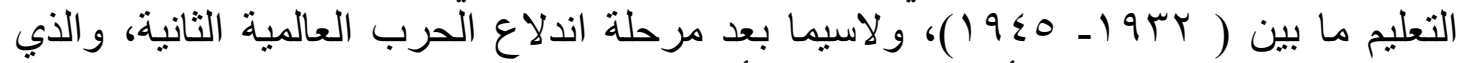

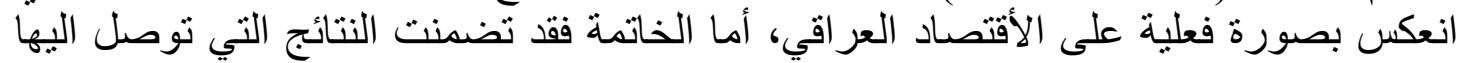
مدى إهتمام مجلس النواب العر اقى بالتعليم وعرض الحلول المناسبة لتطويره والإرتقاء به البحث. وذلك من خلال تناول تمهيد ومحورين وخاتمة.

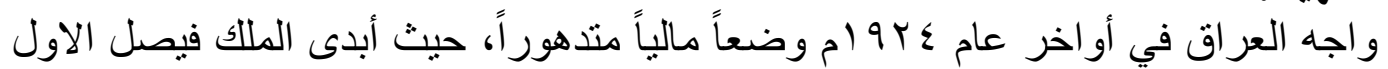

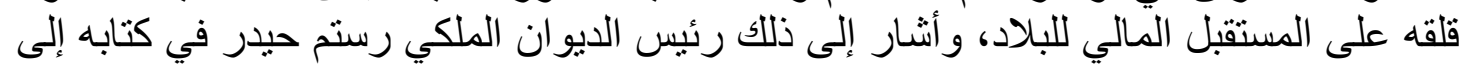

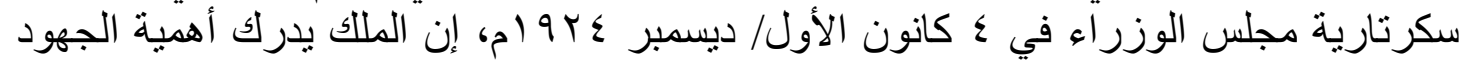

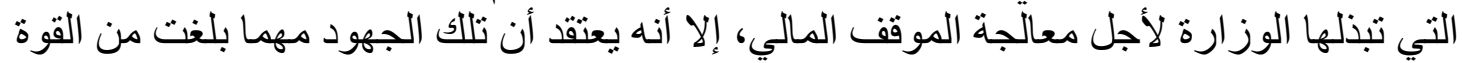
لا تكفي لدرء الخطر القريب، وتأمين التعادل في الميزانية العامة؛ لذلك فهو يتطلع إلى مساعدة 


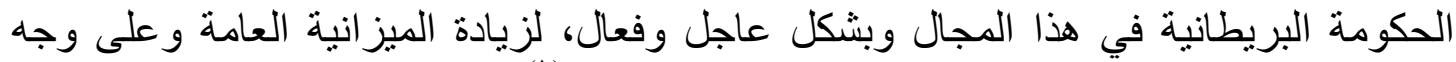

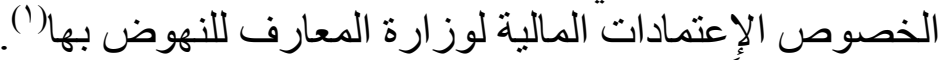

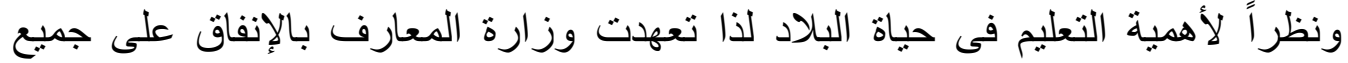

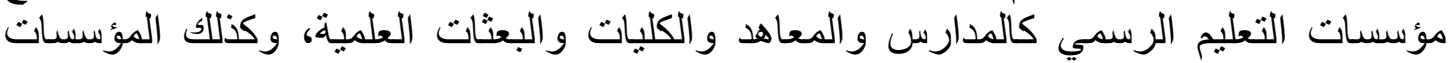
التقافية الأخرى التابعة للوز ارة، كمديرية الآثار و المجمع العلمي العر اقي، بالإضافة إلى ما تقدمه التهات

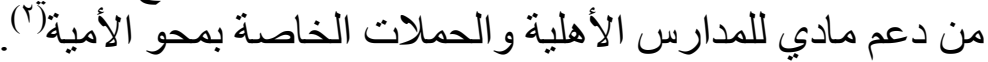

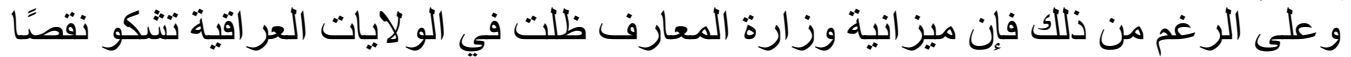

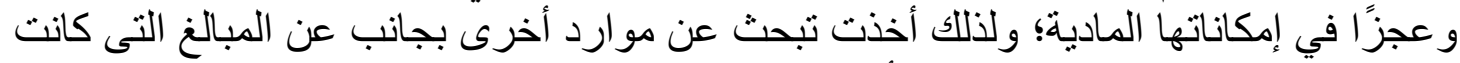

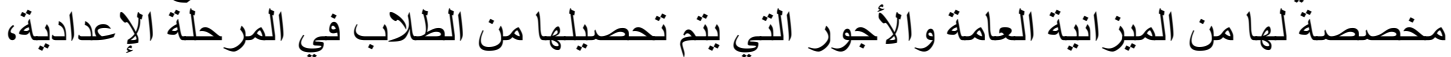

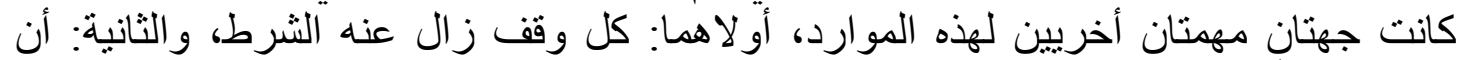

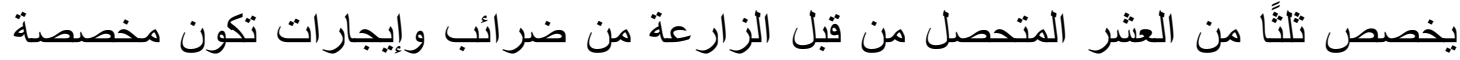

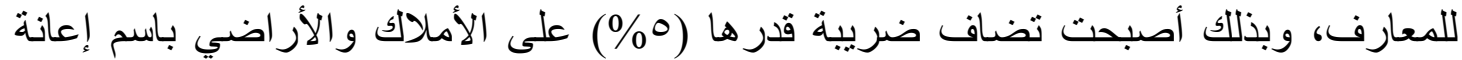

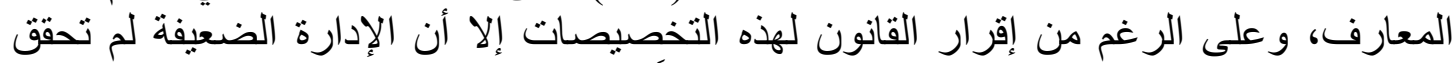

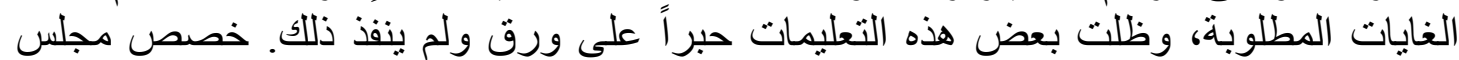

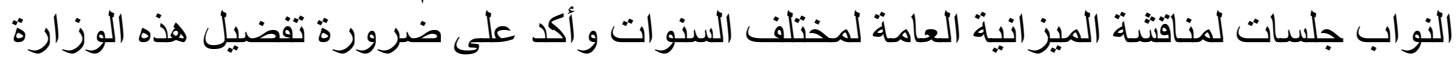

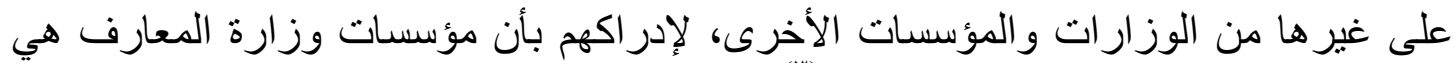

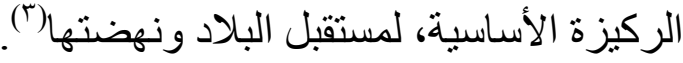

و على أساس هذا الفهم سجل النواب على مدار اجتماعات المجلس مداخلات تضمنت النظر في

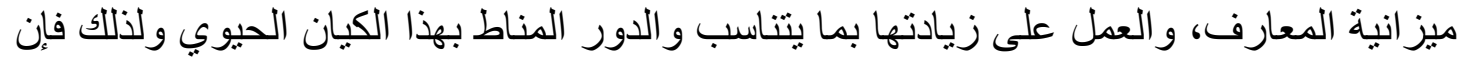

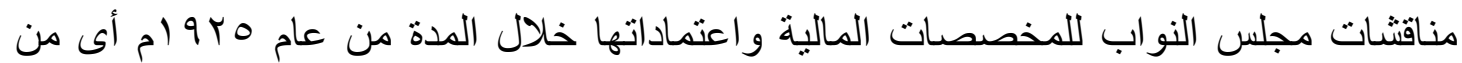

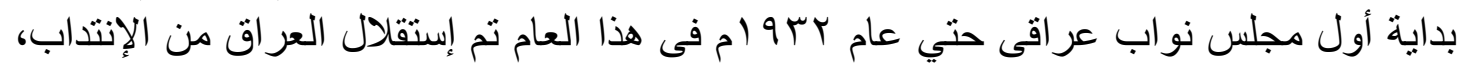

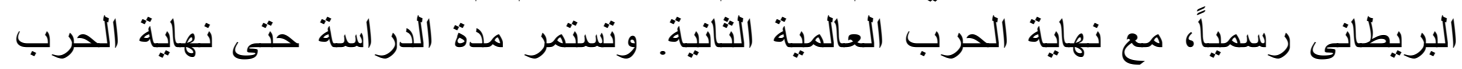

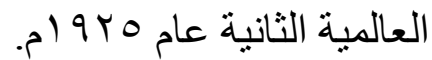

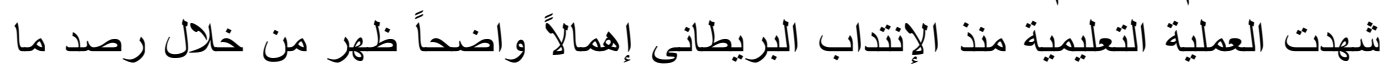

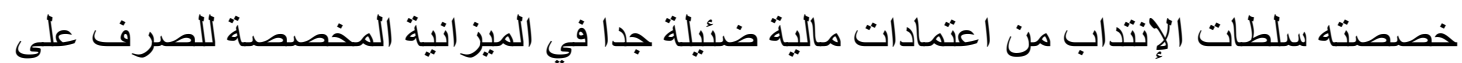

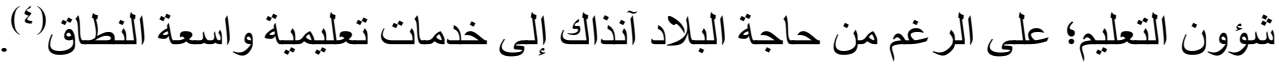

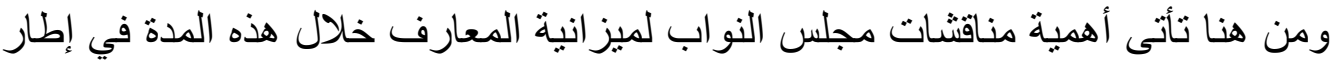

تعهد الوز ارة ذاتها بالإنفاق على جميع مؤسسات التعليم الرسمي في البلاد، سواء في المدارس، أو الكليات أو البعثات العلمية.

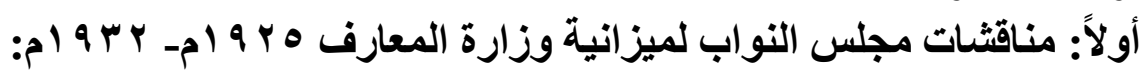

(1) دار الكتب والوثائق العراقية (د.ك.و): ملف البلاط الملكى، كتاب رئيس الديوان الملكى إلى سكرتير مجلس

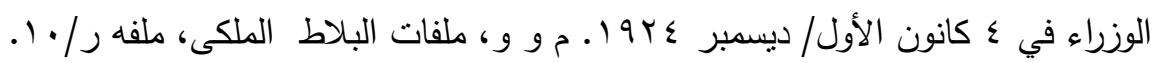

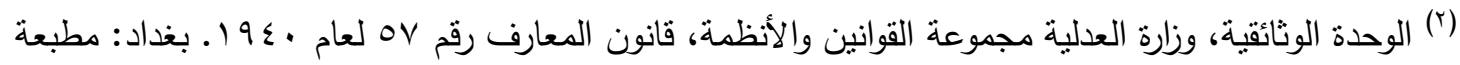

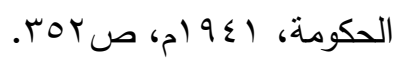

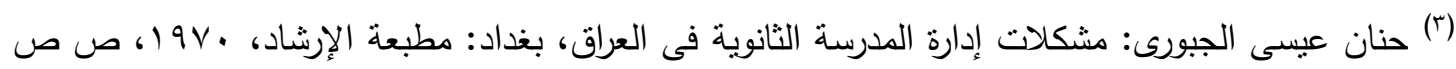

$$
. r \Lambda-r V
$$

(๕) شاكر الأمين: نطور التربية والتعليم فى العراق، محاضرات غبر مطبوعة، بغداد: الجامعة المستتصرية، كلية

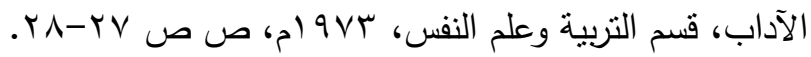




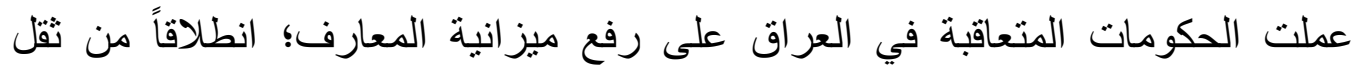

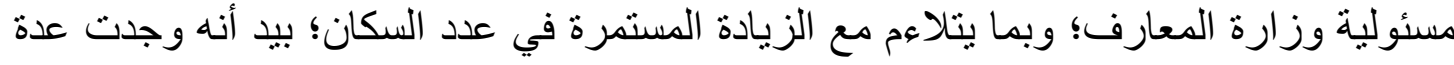

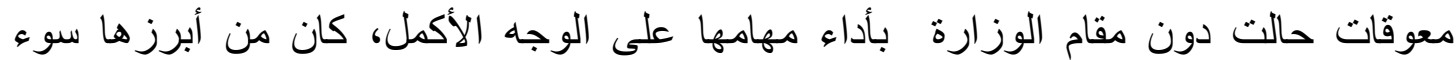

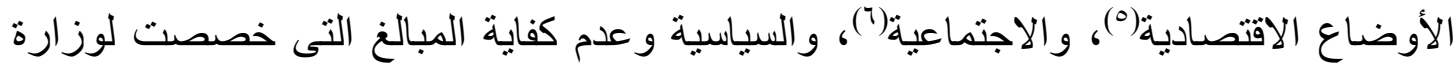

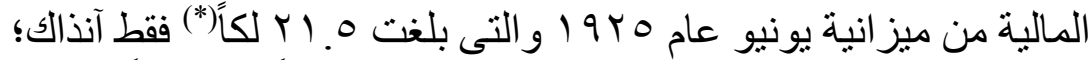

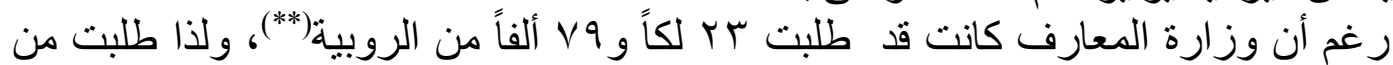

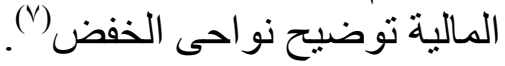

وقد أرسلت وزارة المالية ثلاثة جداول تبين التخفيضات التي تقدها وتتعلق بـ: (أ) أثاث

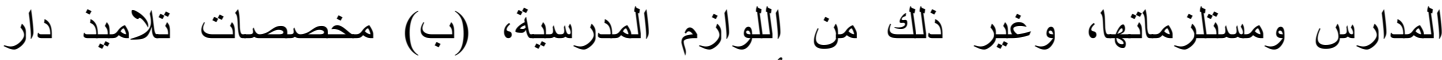
المعلمين،(ج) المساعدات المالية للمدارس الأهلية.

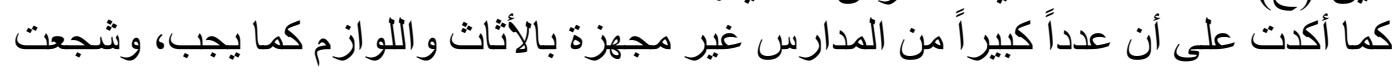

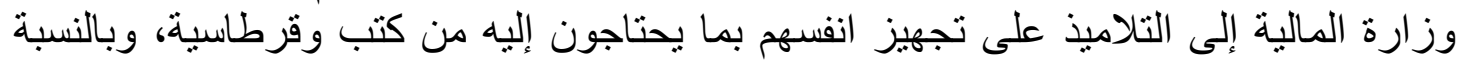

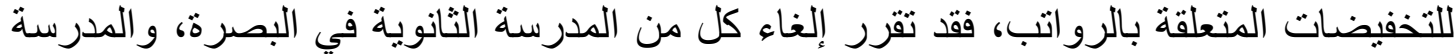

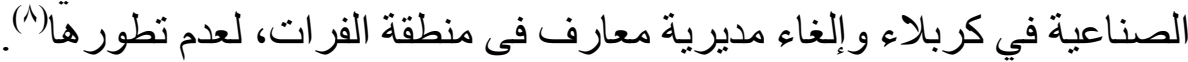

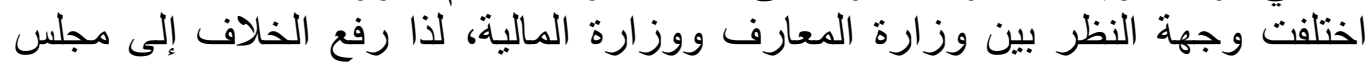

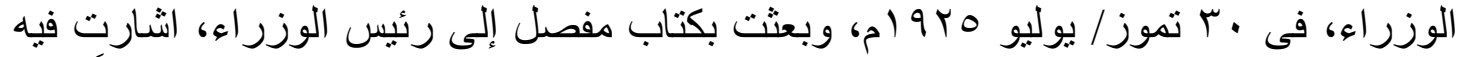

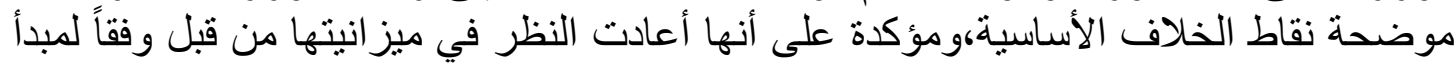

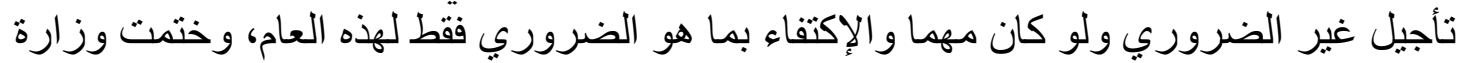

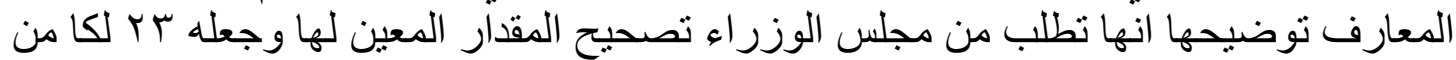

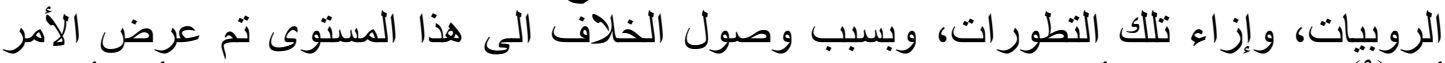

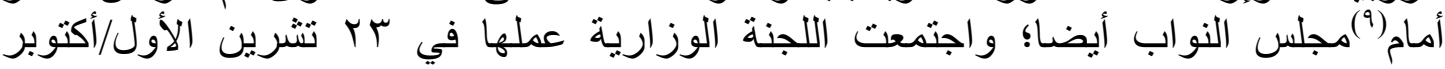

(o) لمزيد من التفاصيل يمكن الرجوع إلى: مصدق جميل: التعليم والتتمية الاقتصادية، بغداد: دار الرشيد،

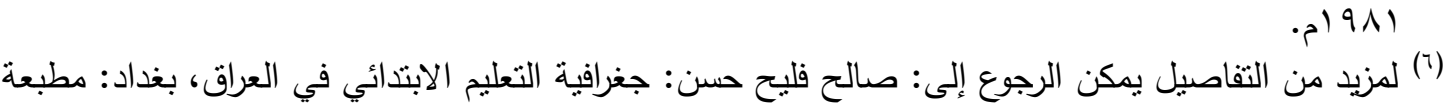

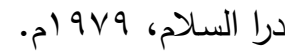

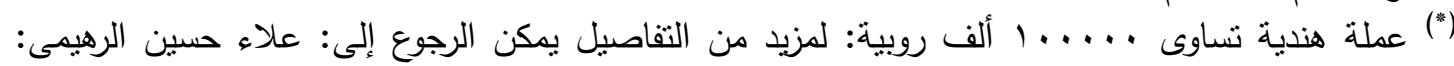

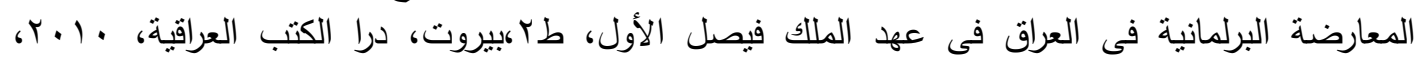

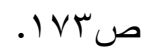

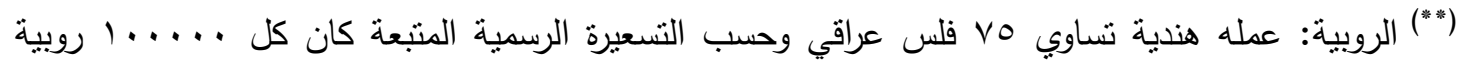

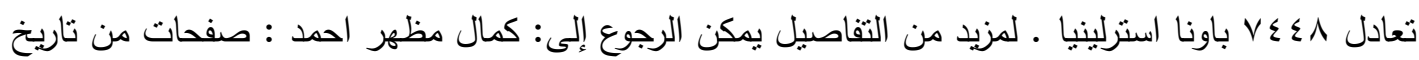

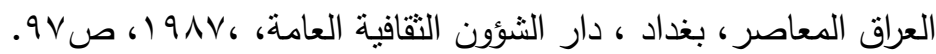

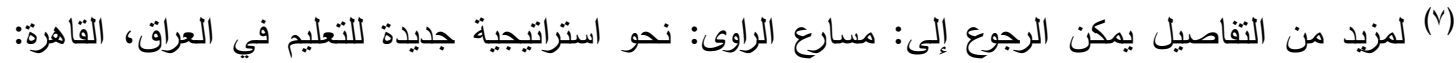

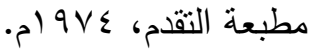

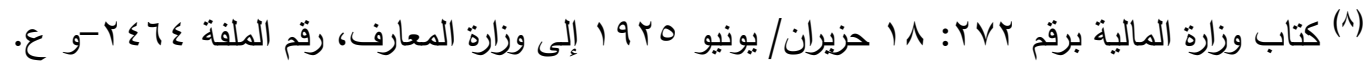

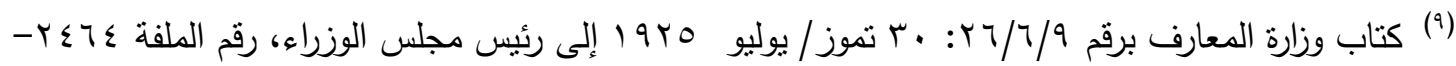


هب (9 م، بالنظر في توصيات لجنة الميزانية بمجلس النواب، بحضور رئيس الوزراء ووكيل

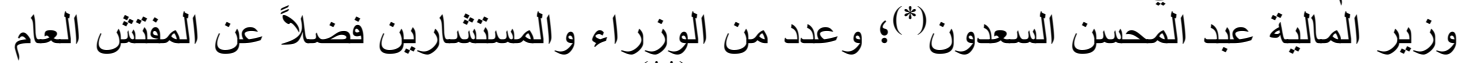
لوز ارة المعارف ليونيل سميث (Lione.F.Smith)

$$
\text { ومدير المعارف ساطع الحصري(*)، وقد تقرر ما يلي (·): }
$$
•المدارس العالية الموجودة ومنذاك، كافية لقبول بجميع الطلاب الذين يتخرجون من الثانية وهي مدرسة الحقوق، ودار المعلمين العالية، و الهندسة. •وضع منهاج التدريس في المدارس الثانوية بصورة تجعل الطلاب مستعدين للإلتحاق بالفروع المختلفة في المدارس العالية. •تطوير الكتب المدرسية.

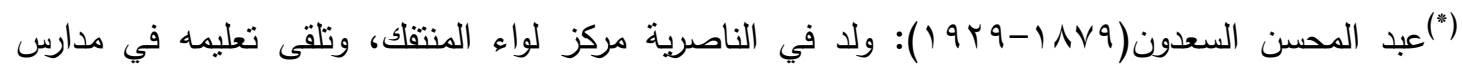

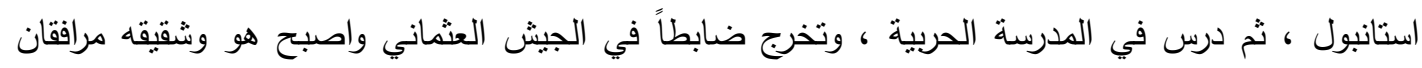

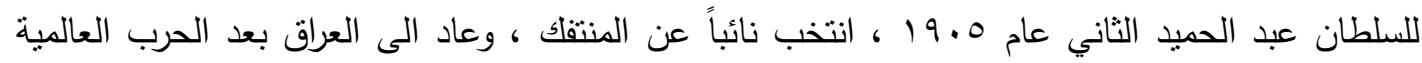

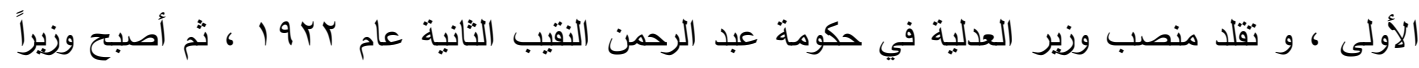

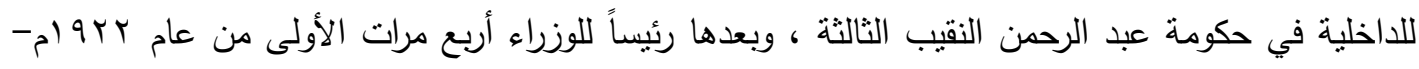

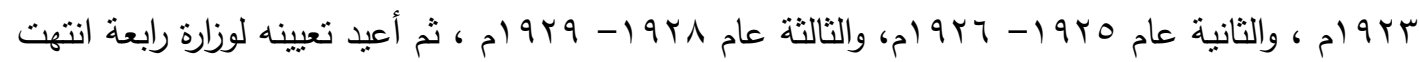

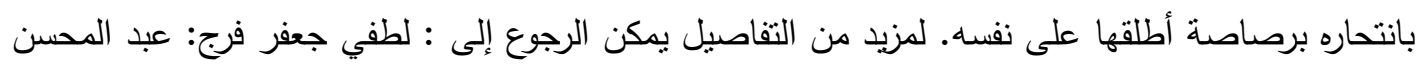

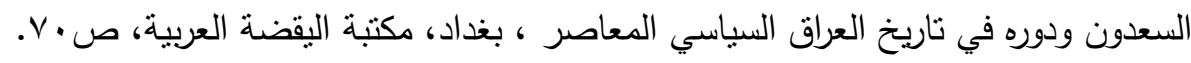

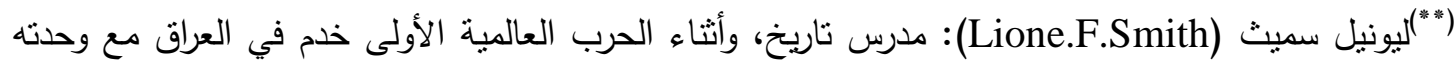

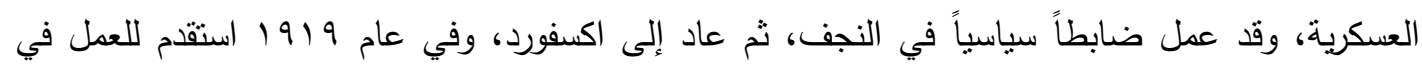

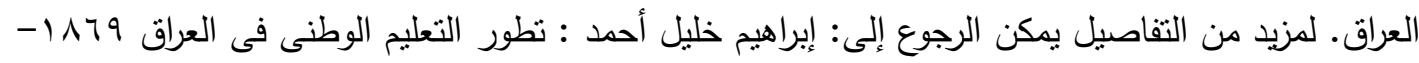

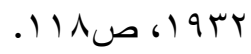

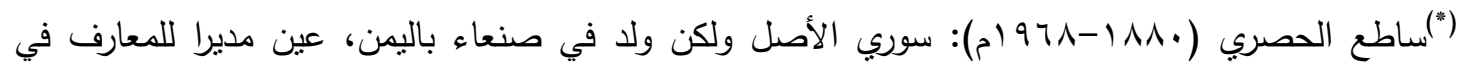

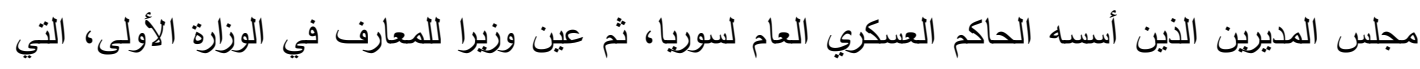
تألفت في 9 ادار/مارس • ب9 ابرئاسة رضا الركابي بعهد الملك فيصل بن الحسين في سوريا وبعد انتهاء

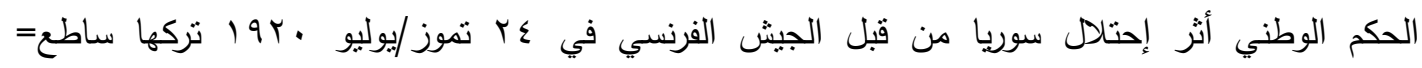

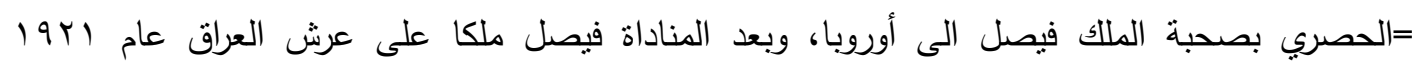

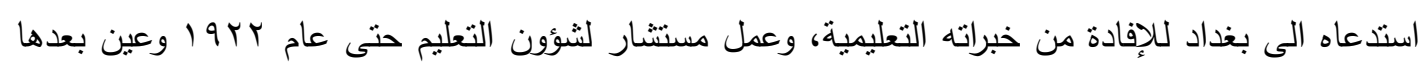

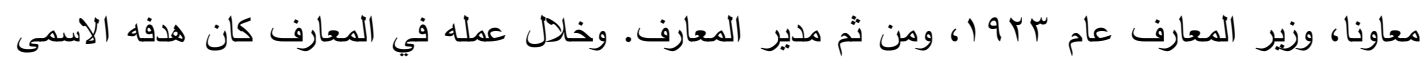
تقوية الثعور القومي وزرع الايمان بوحدة الأمة العربية، وله عدة مؤلفات فى هذا الجانب، لمزيد من التفاصيل

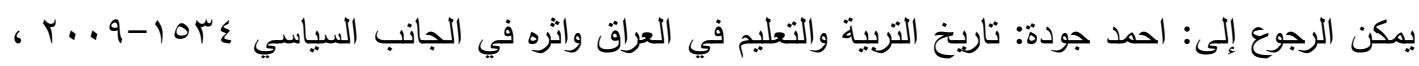

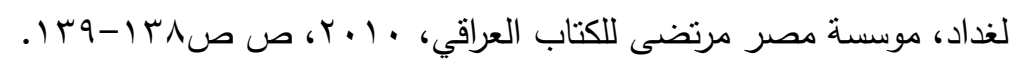

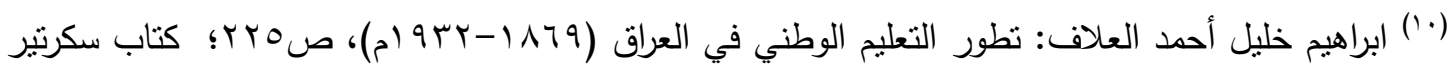

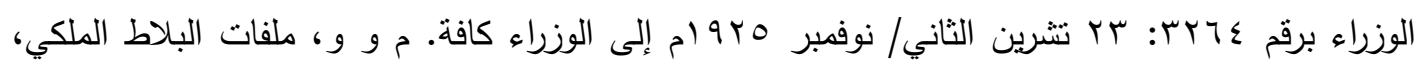


•تعليم أبناء البلاد العلوم الزراعية؛ وذللك بفتح مدرسة للتطبيقات الزر اعية.

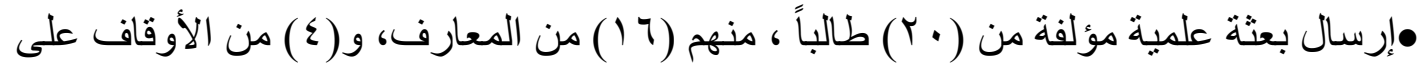
أن يرتبط ذلك بشرطين، أولهما: توفر الأموال، وثانيهما: وجود الطلاب الحائزين على الصفات التي تؤ هلهم لإستكمال الدر اسة في الجامعات الغربية. •زيادة إهتمام وزارة المعارف برفع مستوى دار المعلمين العالية، وتوسيع القبول فيها، ورفضت اللجنة اقتر احين أحدهما: يتعلق بوضع منهج عام للمعارف، وثانيهما: توحيد وزارتي

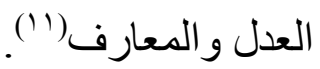

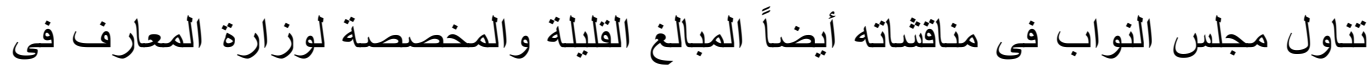
ميزانية الدولة الأمر الذى لفت الإنتباه أيضاً أنظار الصحافة والقوى الوطنية، لذا رأى المجلس

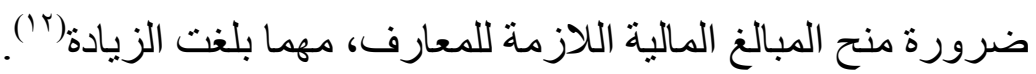

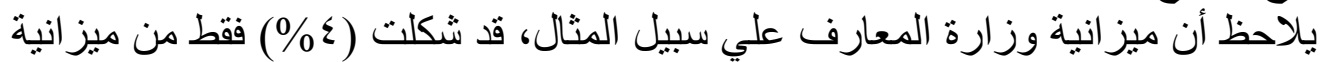

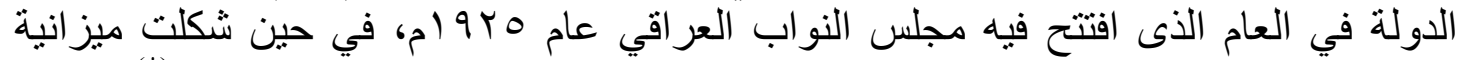

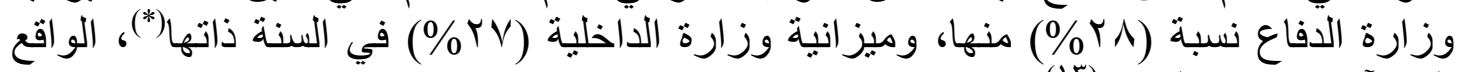

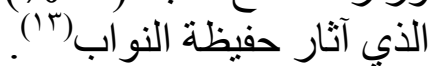
لاقت هذه الميز انية انتقادات كثثرة من أعضاء مجلس النواب أثناء مناقتنتها؛ إذ قال عنها

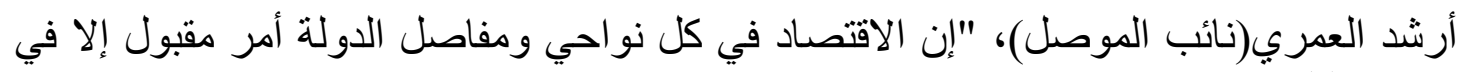

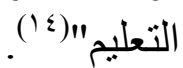
وحول تقرير وزارة المالية بثأن المعارف، رفع عبد اللطيف الفلاحي( نائب الحلة)،

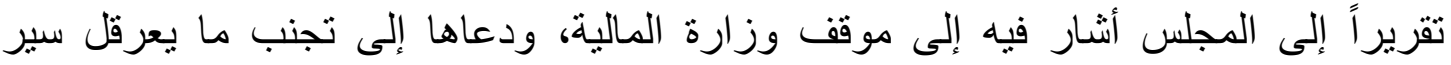
المعارف، قال" إن وزارة المالية اقترحت أموراً لا تتطبق على رؤ روح الإحتياج العلمي في هذه

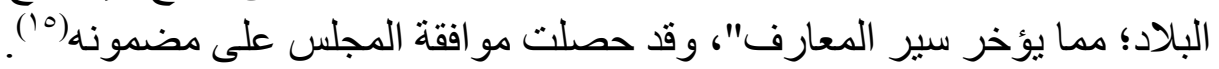

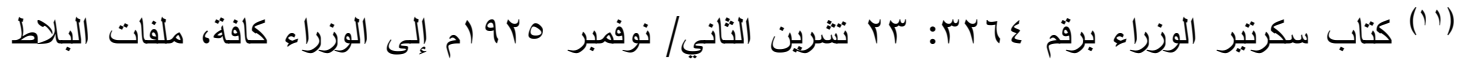

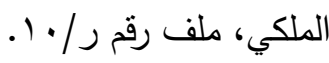

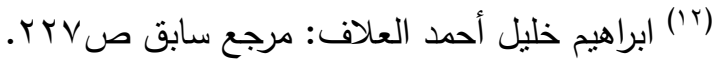

(") أن مخصصات ميزانية وزارة المعارف كانت تزيد على جميع الوزارات والمؤسسات الحكومية الأخرى باستثناء وزارتي الداخلية والدفاع؛ الأمر الذي عده بعض الدتخصصين اهنماماً كبيراً ومسؤولاً من قبل الحكومة آنذاك.

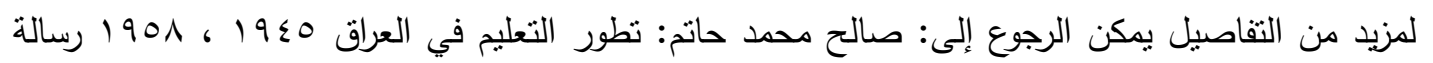

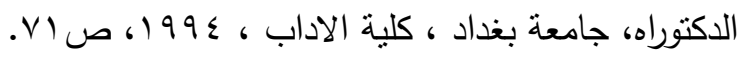

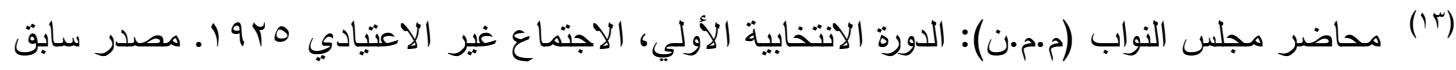
صاדr.

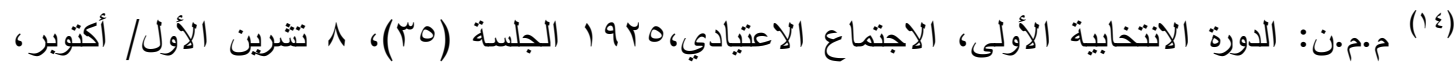

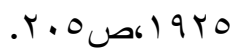

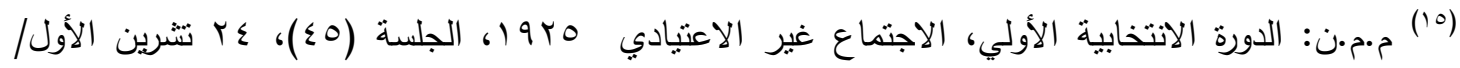

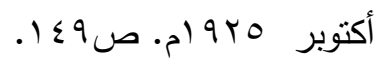


انتقد أيضاً ثابت عبد النور( نائب الموصل)، ميزانية المعارف بشكل عام؛ مشيراً إلى الى إنى

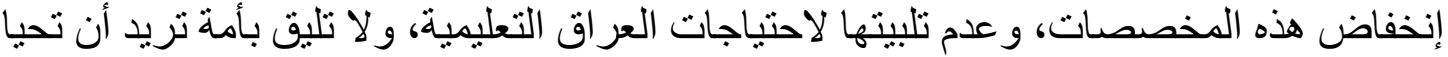

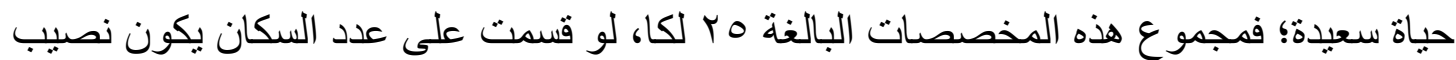

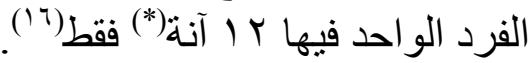
كما دعا الخوري يوسف خياط(نائب الموصل ورئيس لجنة المعارف في مجلس النواب)

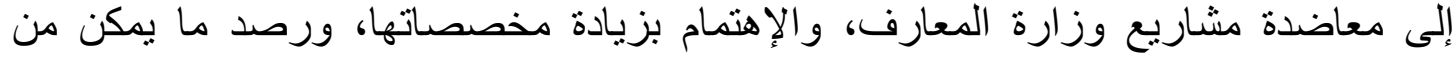

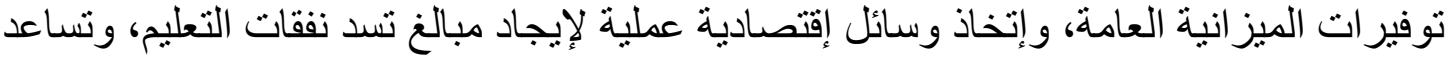

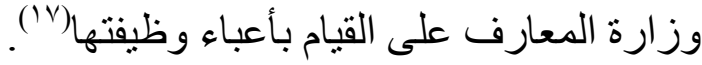

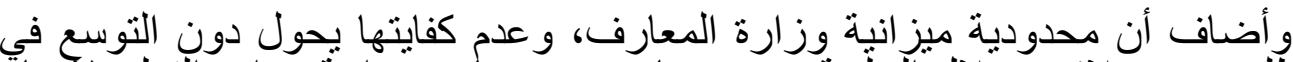

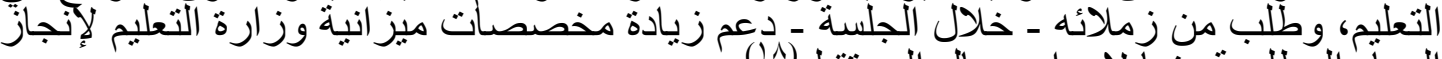

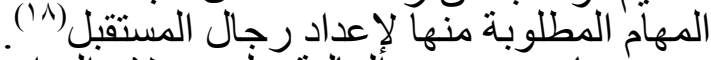

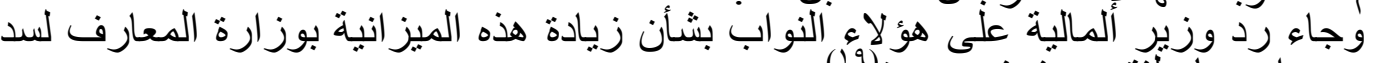

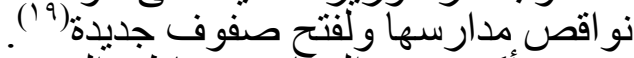

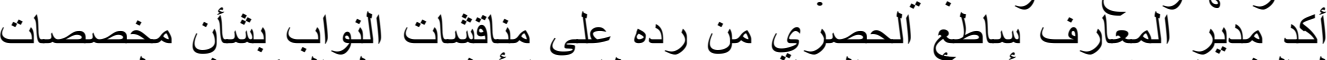

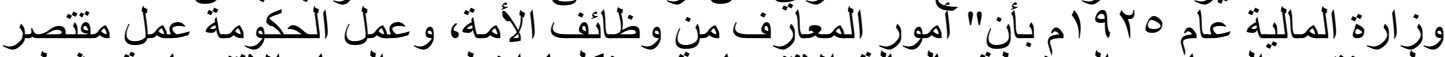

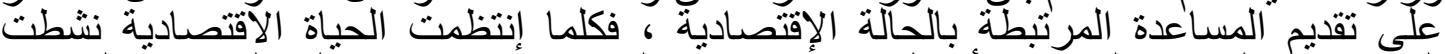

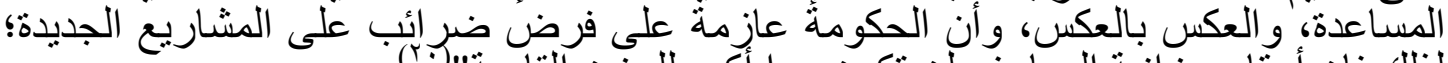

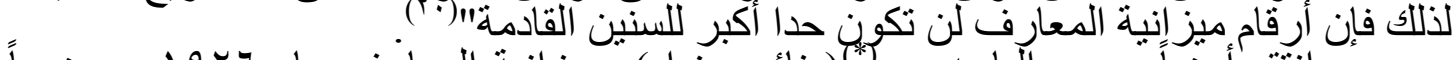

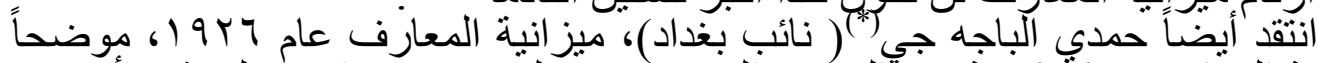

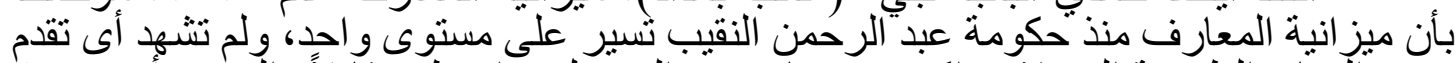

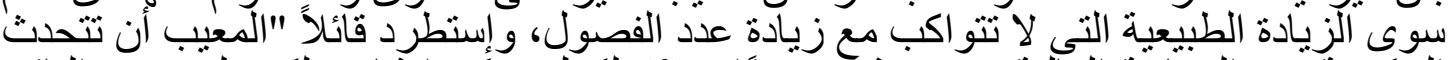

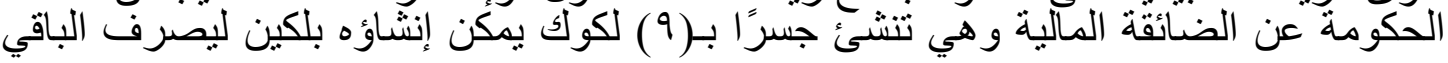

(") آنة: وحدة عملة هندية مصنوعة من النيكل ادخلها الاحتلال البريطاني إلى العراق، يسميها العوام بالعانة

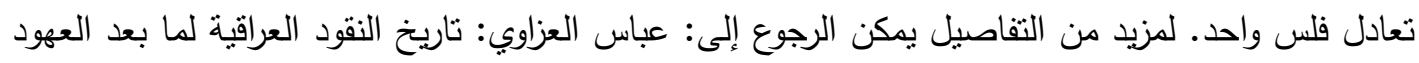

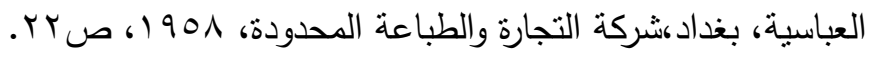

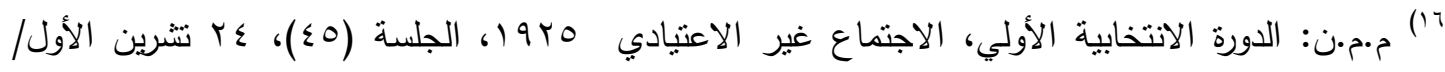

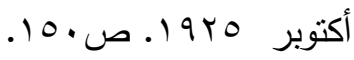

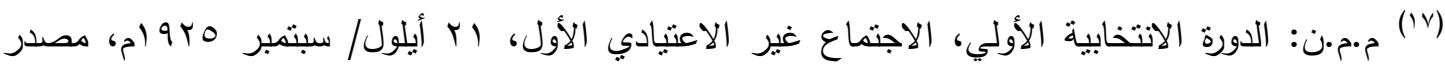

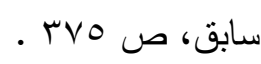

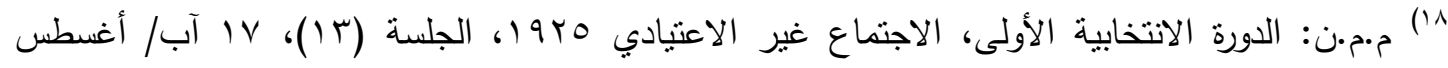

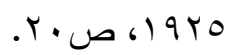

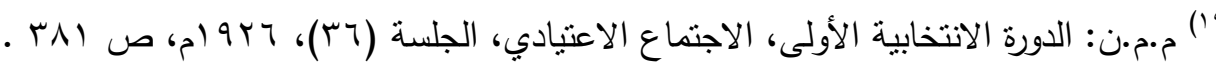

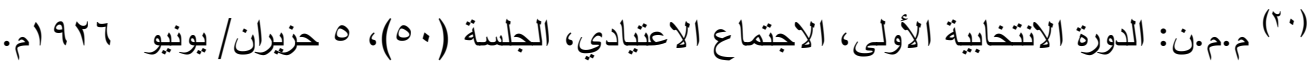

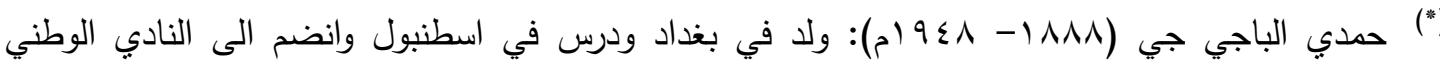

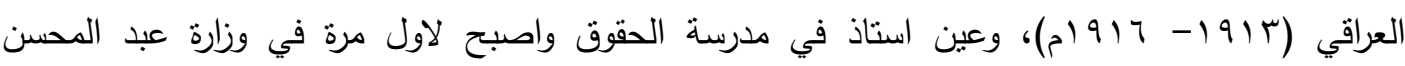

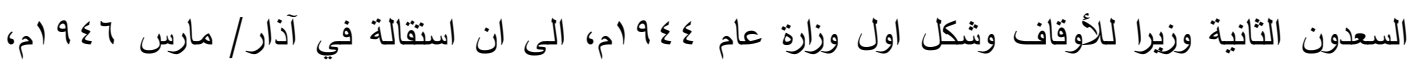

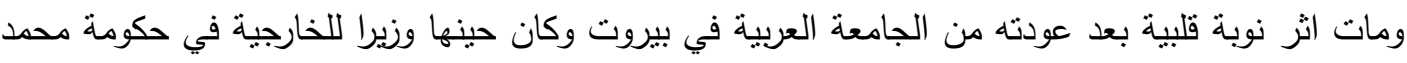

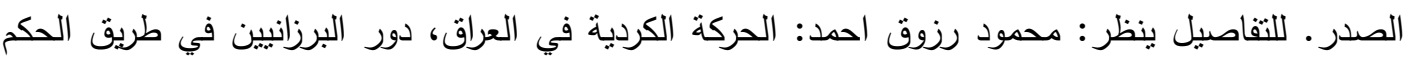

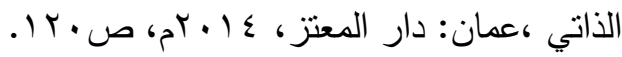




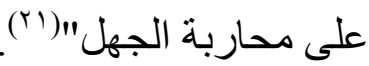

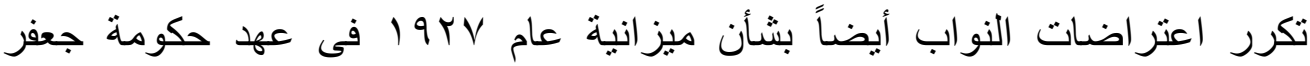

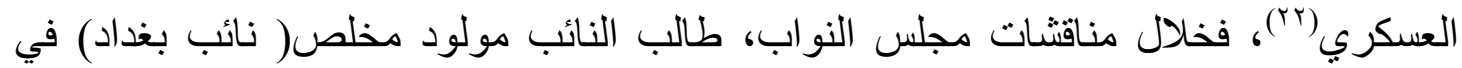

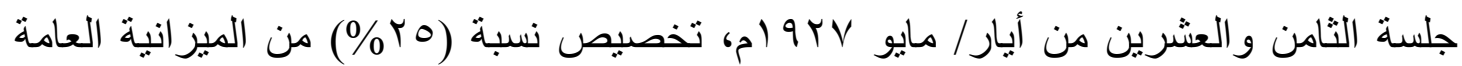

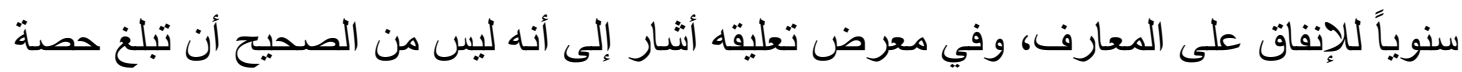

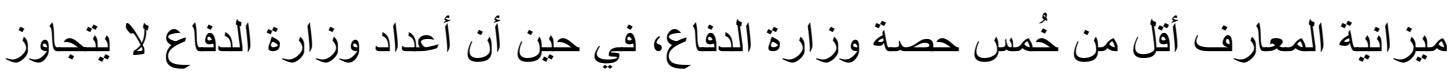
السبعة آلاف شخص، يقابلهم خمسون ألف تلميذ يؤلفون الجيش الحقبقي للبلاد، وربط بين التعليم

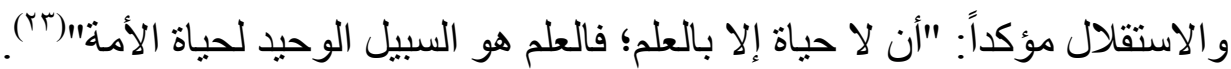

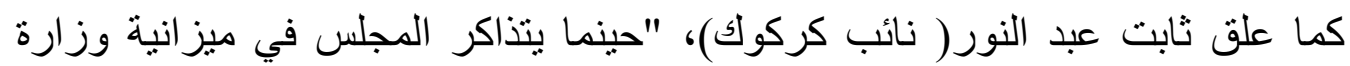
المعارف يشكو النواب مر الثكوى من النقص البارز في هذه الأمور وينتقدون أشند الانتقاد الخطة التي نسير عليها في تثقيف أبناء الأمة وتعليمهم العلم الصحيح؛ إذ يؤلفون في المستقبل أمة

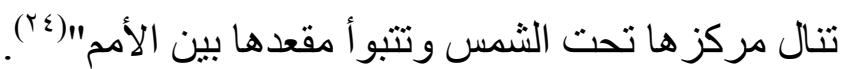
و عن عدم تلبية مخصصات المعارف لأهداف الدولة العراقية، نفى تعليق النائب أحمد

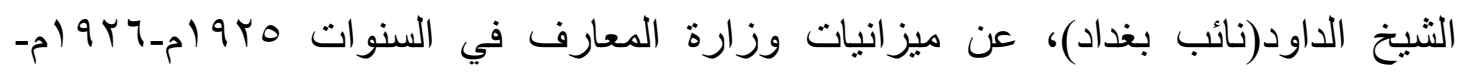
9 TV

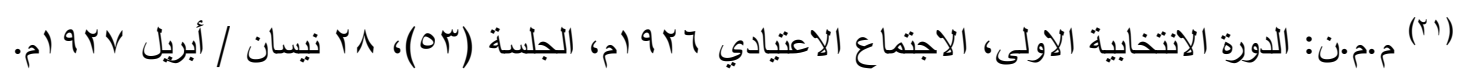

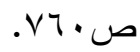
جعفر العسكري (110 ام - - جسو (م)، ولد في بغداد واكمل دراسته التمهيدية الاولية ثم العسكرية التحضيرية

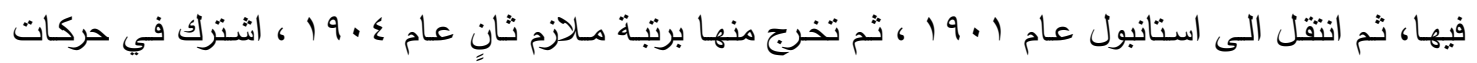

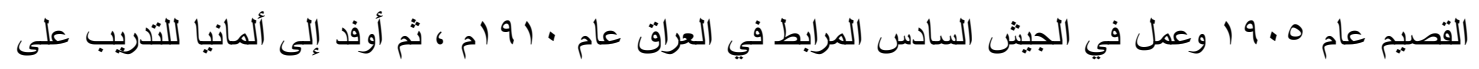

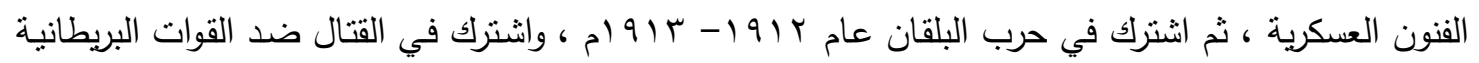

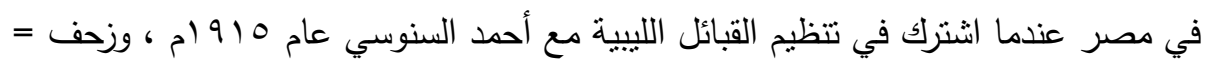

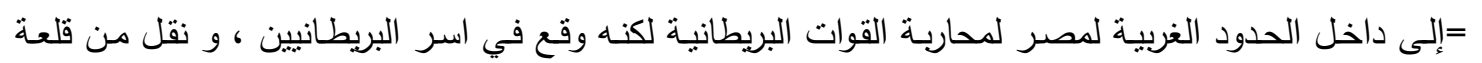

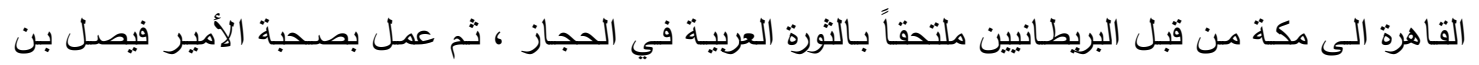
الحسين عندما أصبح ملكاً على سوريا ، و عين وزيراً للاففاع في وزارة عبد الرحمن النقيب الأولى ، ثم عين رئيساً

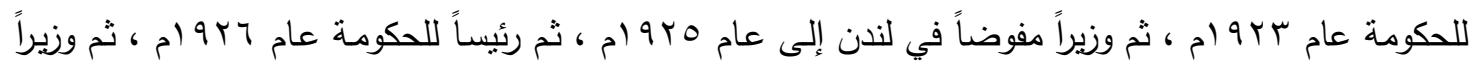
مفوضاً فوق العادة في لندن ، وقد نولى عدة مناصب وزارية وحكومية حتى اغتياله ،اثر انقلاب بكرصدقي. لمزيد

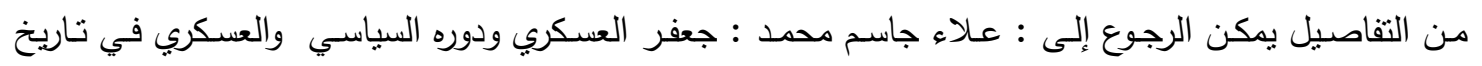

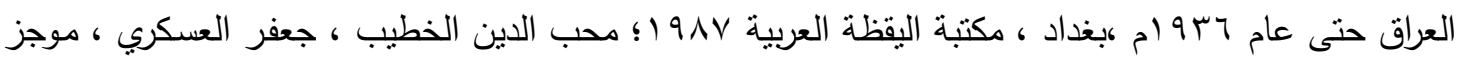

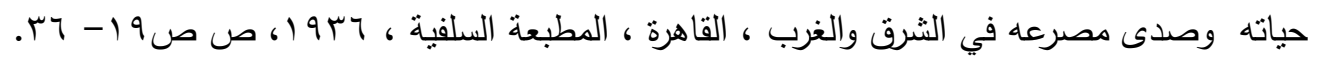

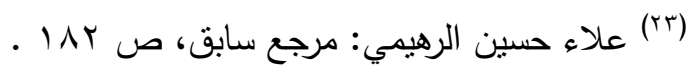

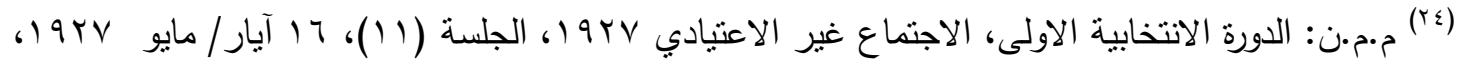
ص صـ 1.10$)$

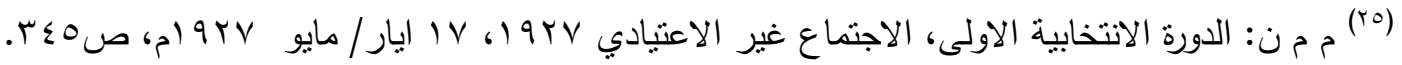


وخلافاً لميز انيات المعارف في الاعوام السابقة فقد ارتفعت فى ميز انية عام ^بو (؛؛ حيث

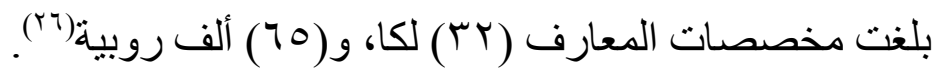
أستمر أعضاء مجلس النواب معارضتهم للمبالغ المرصودة لوزارة المعارف في ميز انية الدولة موضحة بأن هذه الميزانية لا تحقق المرجو منها وذلك من منطلق حرصهم على أهمية

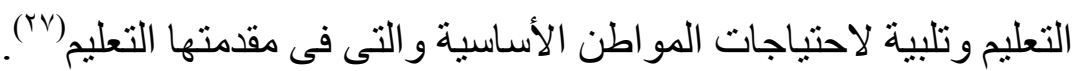

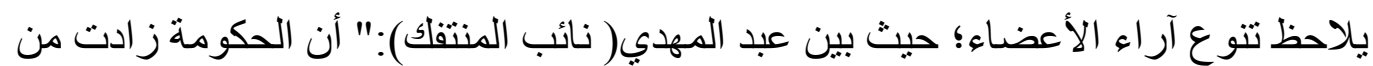
مخصصات المعارف بنحو لكين، ولكن هذه الزيادة تؤمن فتح 7 مدارس جديدة فقط، والبلاد

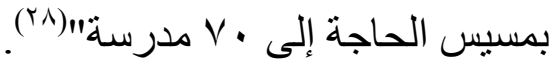

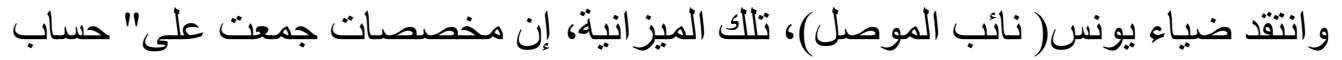
المو اطن فلابد من صرف جزء مناسب منها على إحتياجات المو اطن الأساسية، وفي مقدمتها حقه

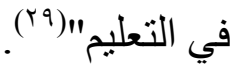

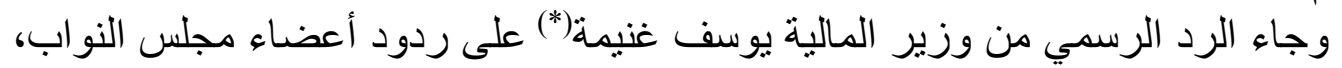

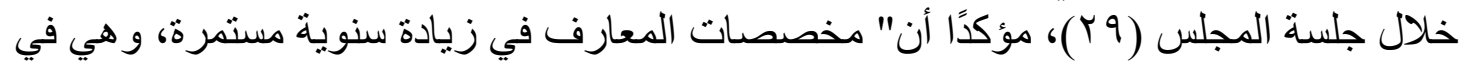

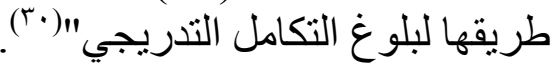

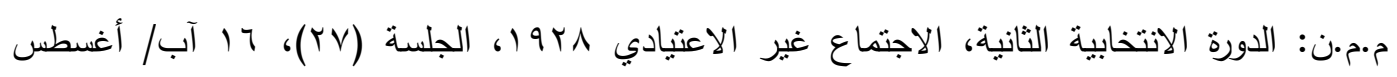

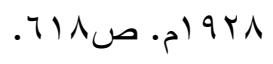

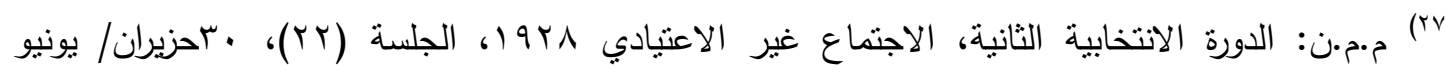

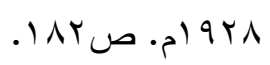

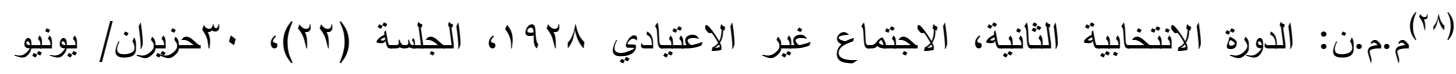

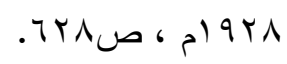

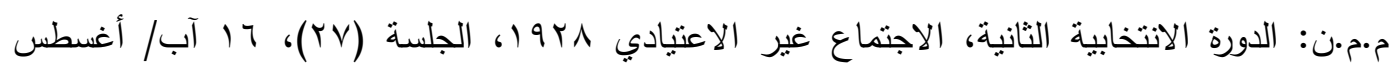

$$
\text { . Tr }
$$

(") يوسف غنيمة (1110- . 1901): السياسي والأديب يوسف رزق الله غنيمة، كلداني كانوليكى، اصله من بغداد، درس في مدارس الآباء الدومنيكان في بغداد، عضو مجلس النواب العراقي للدورة الاتتخابية الأولى،

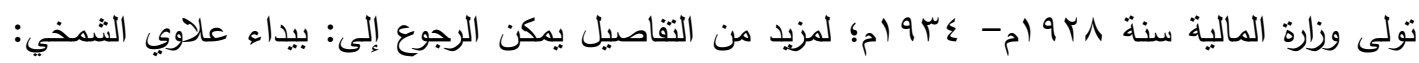

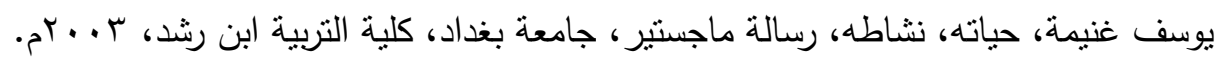

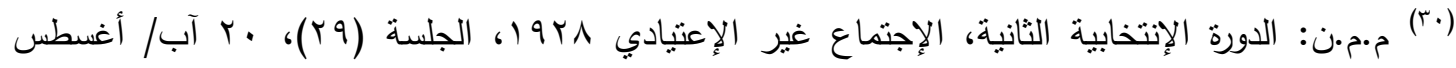

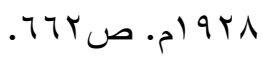

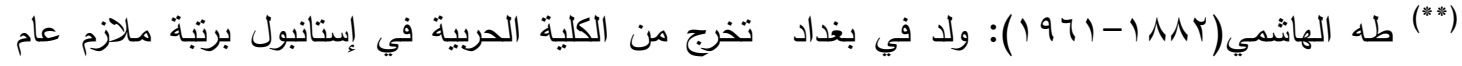
7.9 19، درس الأركان وتخرج عام 9.9 1، استقال من الجيش العثماني والتحق بالجيش العراقي بعد قيام

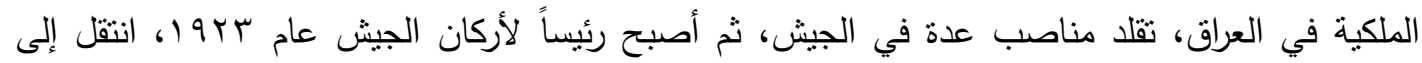
وظيفة مدنية عام § 9 (، وفي العام نفسه عهدت إليه رعاية الملك غازي وتعليمه، ثم عين مديراً عاماً للنفوس

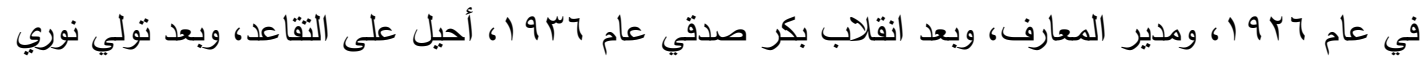
سعيد الوزارة الثالثة عام ^هـ 1، أصبح وزيراً للافاع، ثم استوزر بعد ذبع ذلك أكثر من مرة لمزيد من التفاصيل 
وقد أشار طه الهاثنى مدير المعارف فى معرض رده على اعتر اضات النواب(**) إلى في

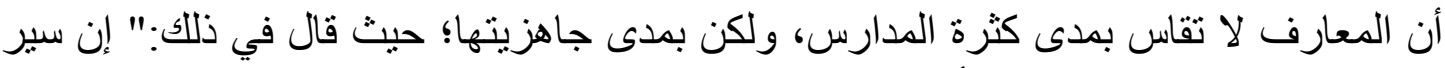

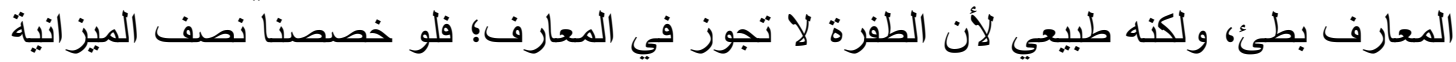

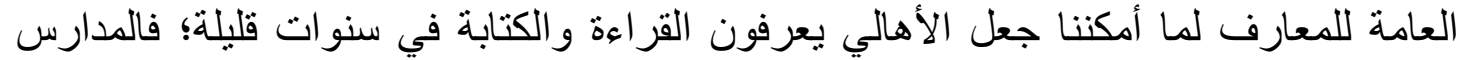

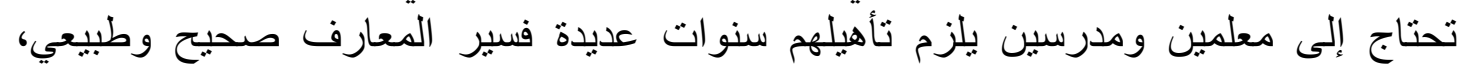

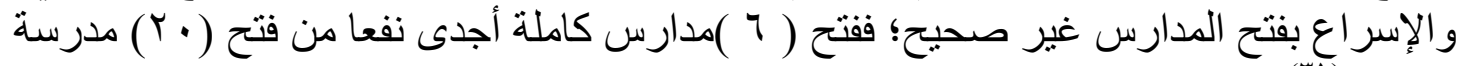
ناقصة"|(r)

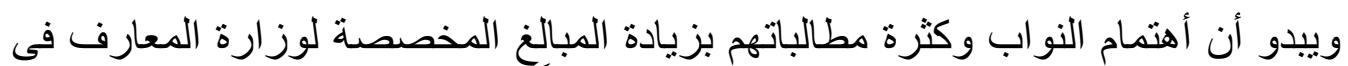

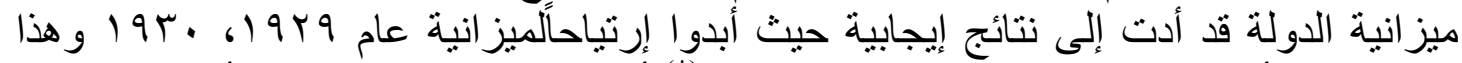

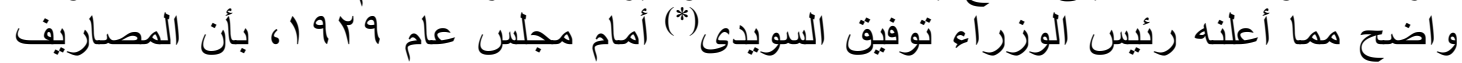

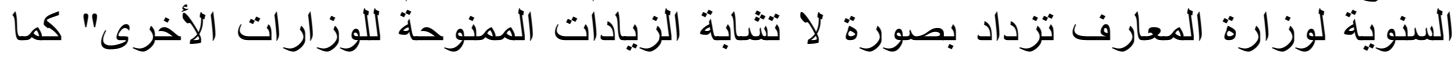

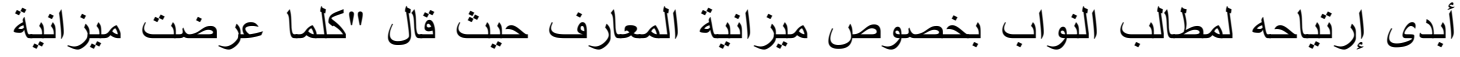

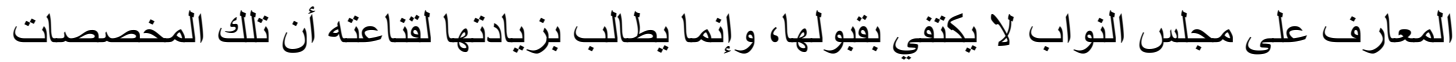
تسهم في تهذيب الأمة، وأن الحكومة لتقدر هذا الموقف النبيل للمجلس، وستبذل قصارى جهدها

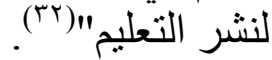

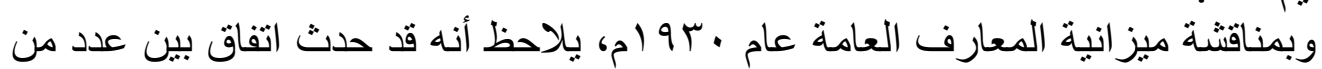

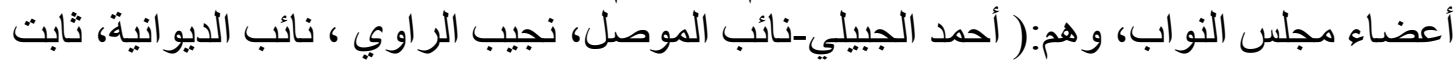

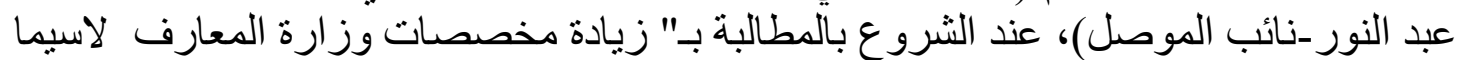

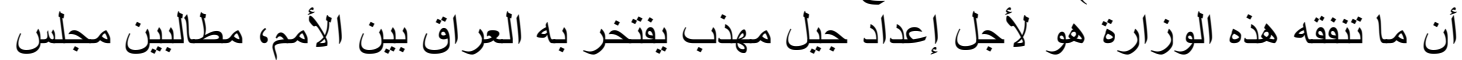

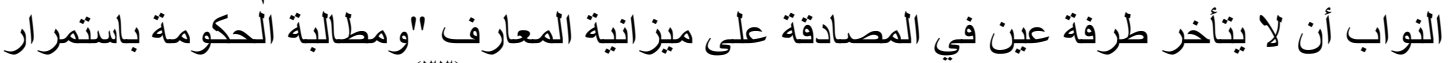

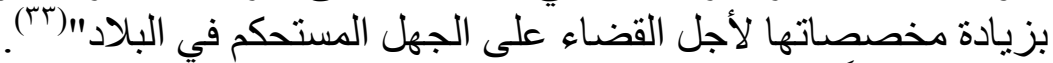

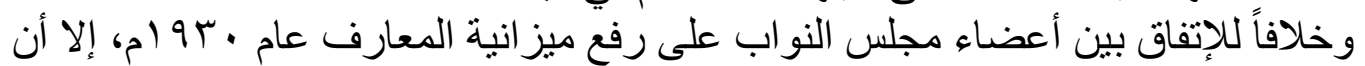

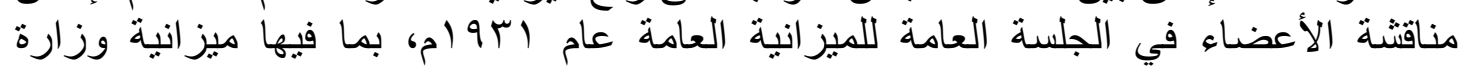

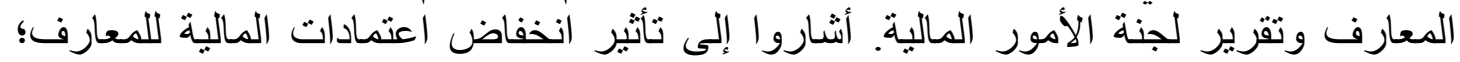

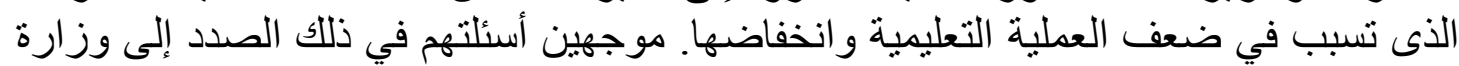

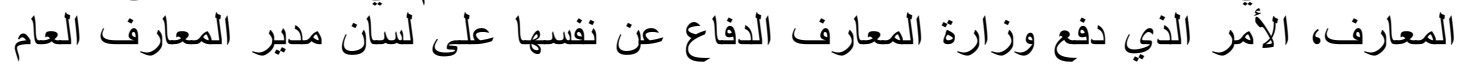

يمكن الرجوع إلى: فليح حسن علي : عبد الرزاق الحسني مؤرخاً، بيروت ، دار مكتبة البصائر، 11، ص 11.10

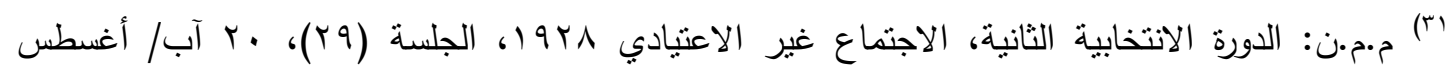

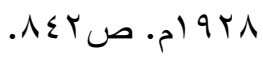

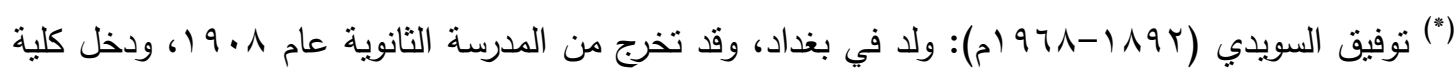

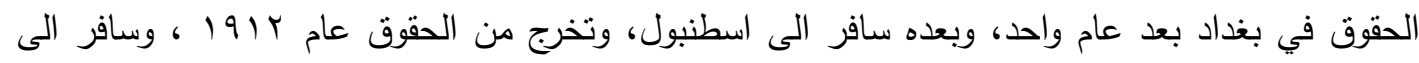

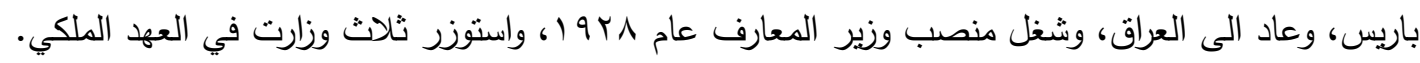

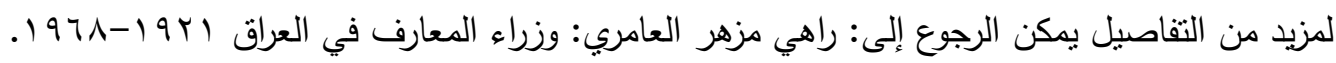

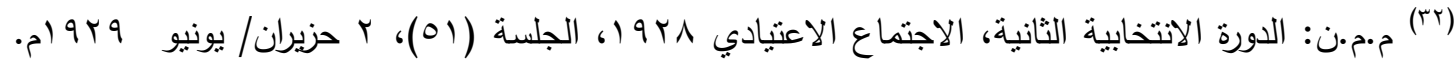

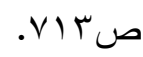

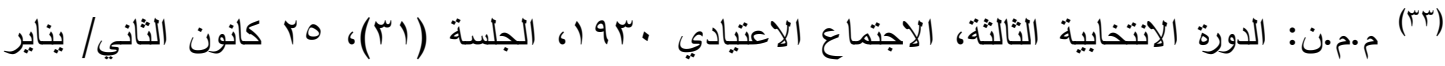




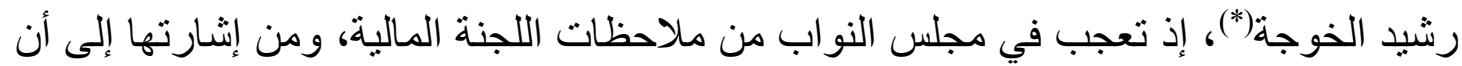

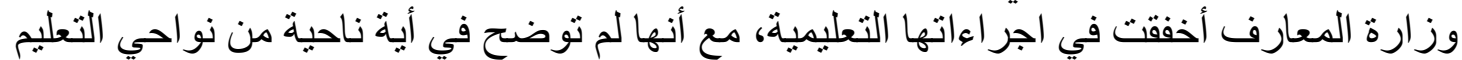
كان هذا الإخفاق، قائلاً:" كانت وزارة المعارف توان أدارد أن تبني اللجنة أحكامها على تدقيقات علمية

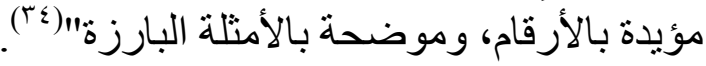

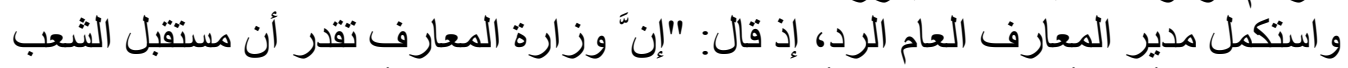

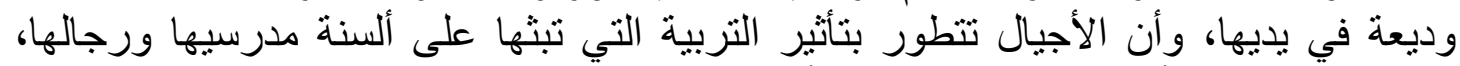

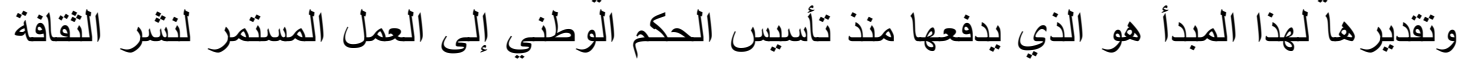

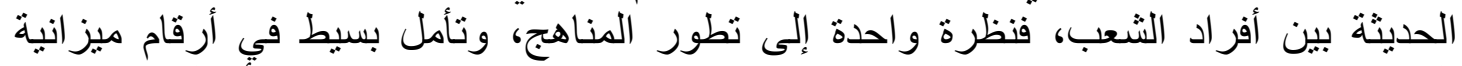

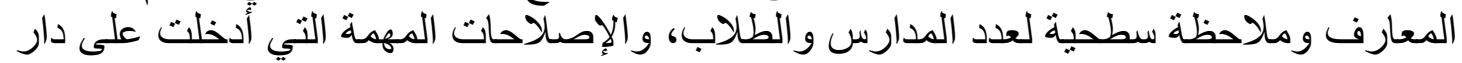

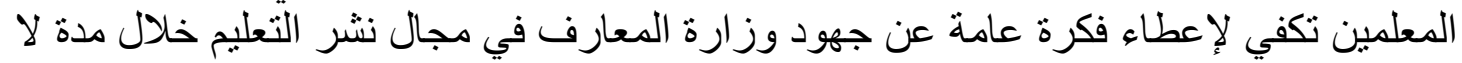

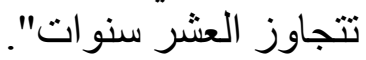
وبهذه المناسبة استنكر غياث الدين النقشبندي( نائب الموصل)، زيادة ميزانية الجيش

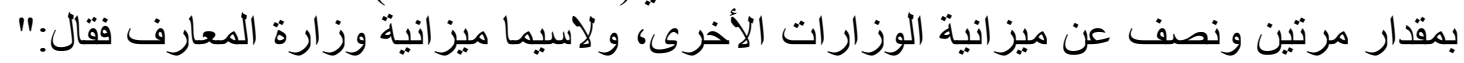

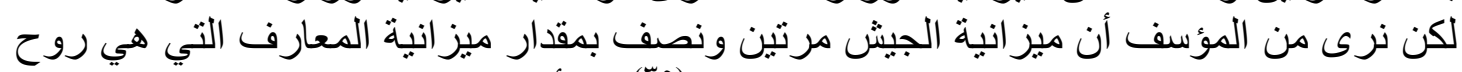

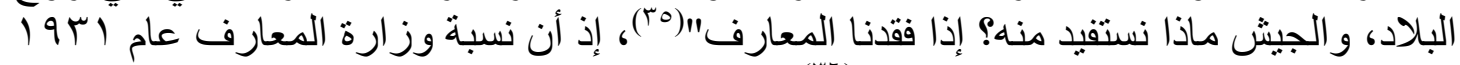

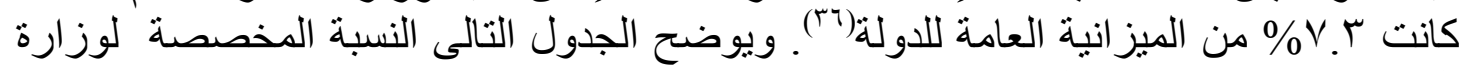

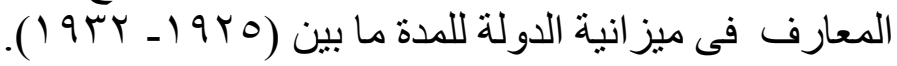
لسنة المالية

\begin{tabular}{|c|c|c|c|}
\hline$\% \varepsilon . Y$ & IVIOKY & $\varepsilon \cdots \varepsilon+\leqslant q$ & م) \\
\hline $0 \leqslant \varepsilon$ & $1 \wedge \leqslant 17 \mu$ & EIYY।97 & م) $9 r V-219 r 7$ \\
\hline $0 \leqslant .7$ & $r .1070$ & $\varepsilon \curlyvee \wedge \ldots \neg \wedge$ & م) $9 r \Lambda_{-} / 9 r V$ \\
\hline \% & r. YAVA & $\varepsilon \Psi ! \leqslant V \cdot 1$ & م)9r9-p19r人 \\
\hline $0 \% 7.1$ & $r V \cdot \varepsilon r \Lambda$ & $5 M 7.707$ & م) \\
\hline \% & YqEY & rqq & . \\
\hline
\end{tabular}

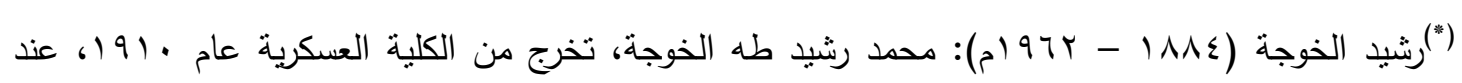
تأسيس الحكومة الوطنية عام • ب9 ام شغل منصب منصرف لواء بغداد ثم الموصل، كما عمل مدير عام

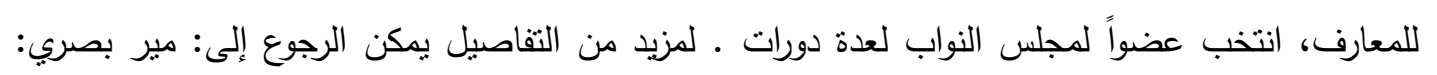

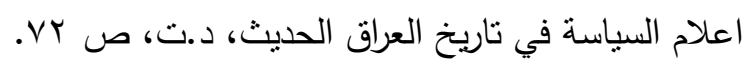

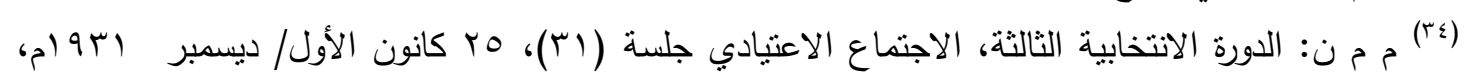

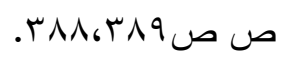

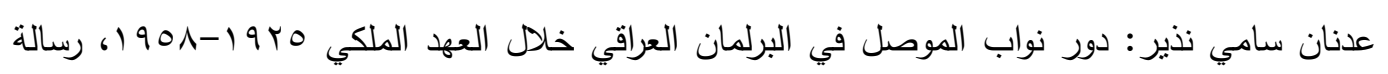

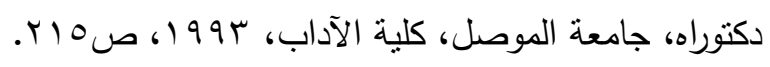

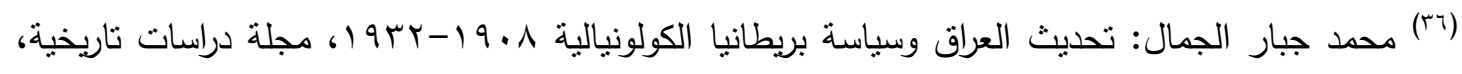

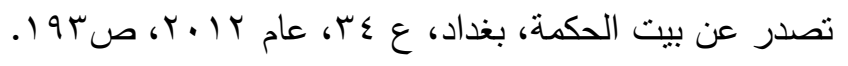




\section{$\%{ }^{\wedge} .{ }^{\top}$}

rqur. ร

roTV^91

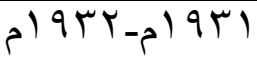

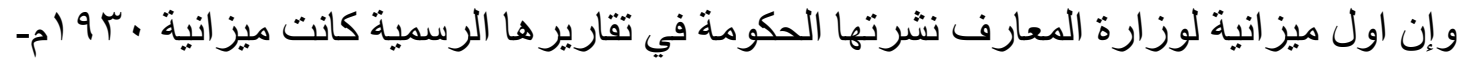

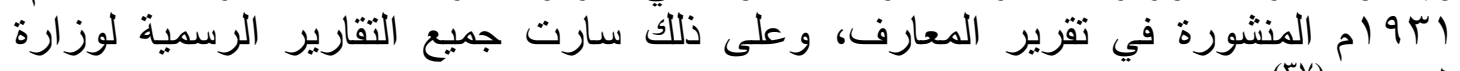

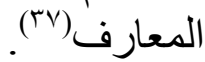

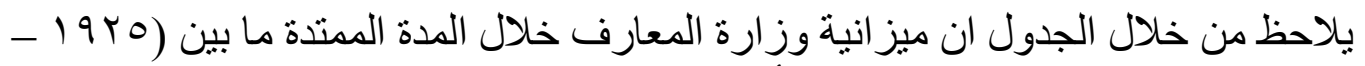

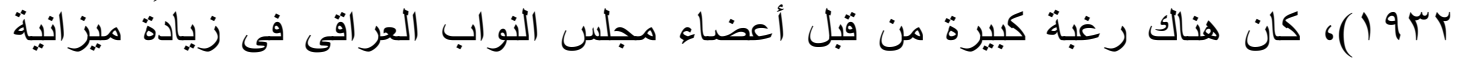

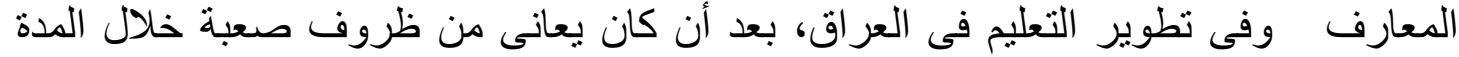

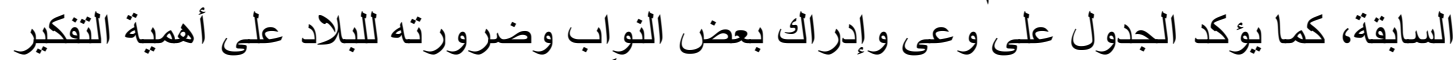

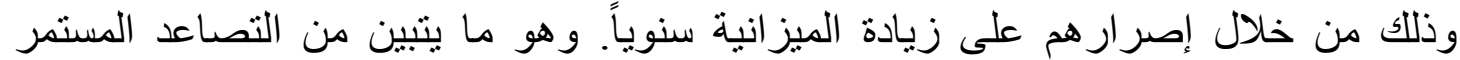

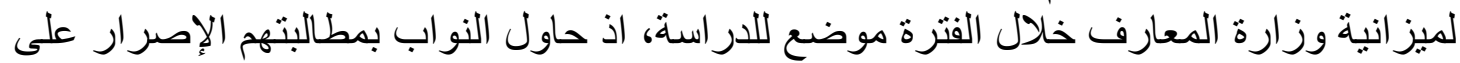

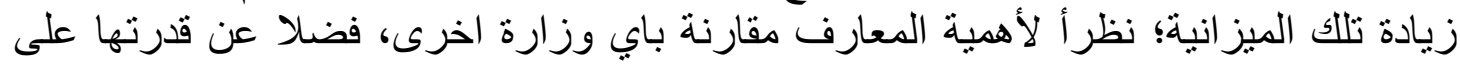

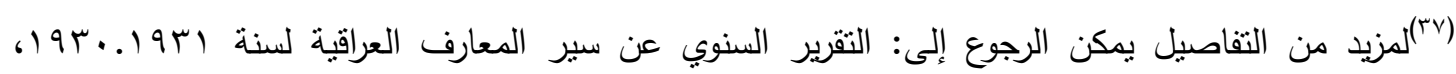

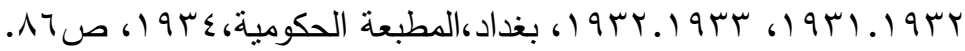

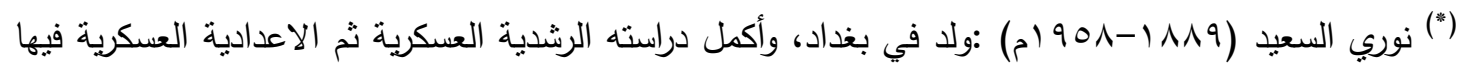
، ثم التحق بالكلية العسكرية في استانبول وتخرج منها عام 7 ا9 1، ساهم في نشاط جمعية العهد السرية

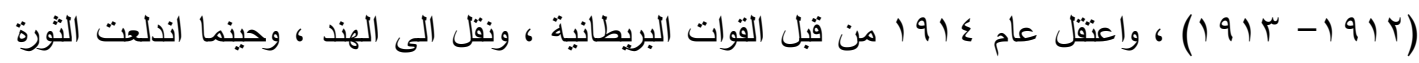
العربية في الحجاز عام 1917 التحق في صفوفها بإمرة الأمير فيصل بن الحسين ، وعمل رئيساً لأركان

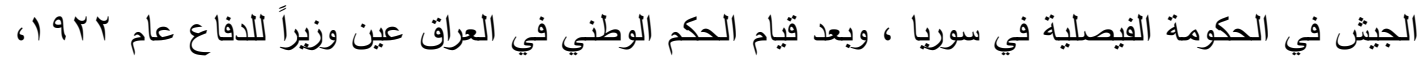

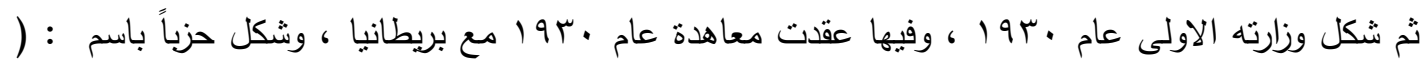

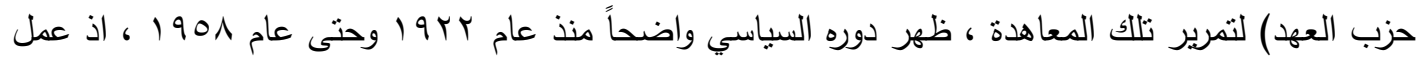

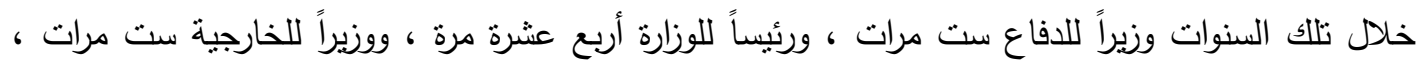

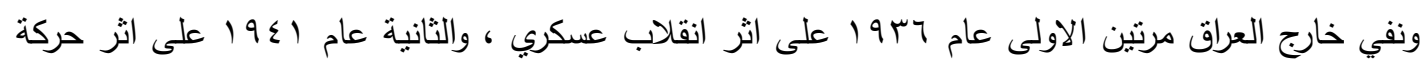
رشيد عالي الكيلاني قتل في شهر تموز ـ لمزيد من التفاصيل يمكن الرجوع إلى : سعاد رؤوف شير التير محمد :

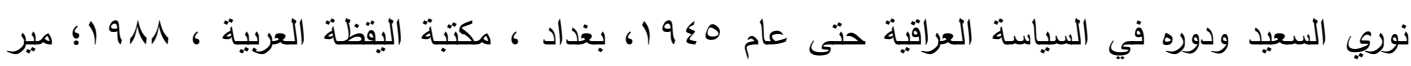

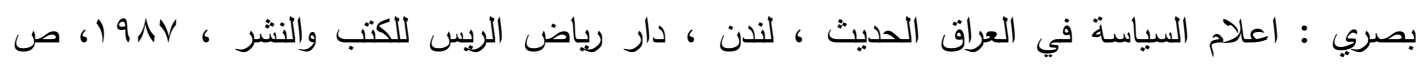

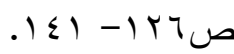

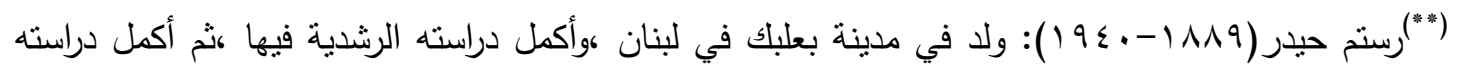

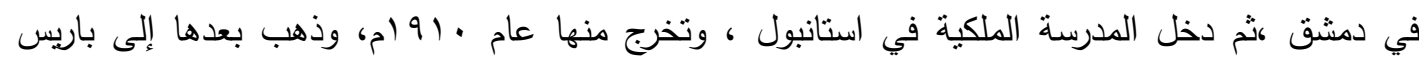

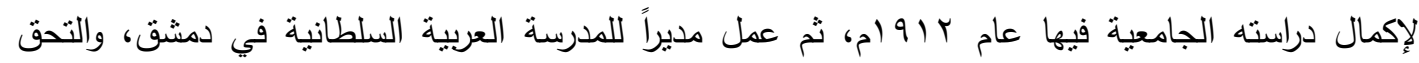
ضابط احتياط في الجيش العثماني في اثثاء الحرب العالمية الأولى، وفي السنة الأخيرة من تلاك الحرب إلتحق بجيش الامير فيصل بن الحسين أثناء الثورة العربية الكبرى ، وبعد قيام الحكم الملكي في العراق عين سكرنيراً

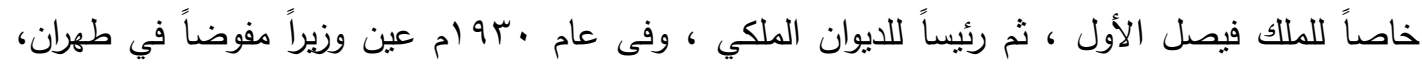

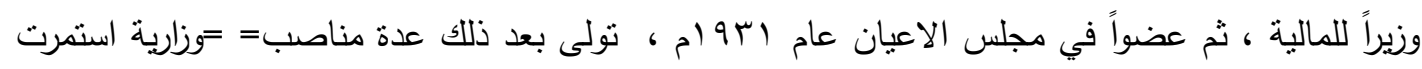

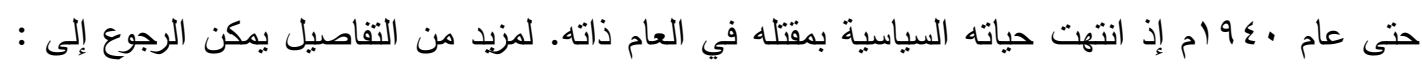

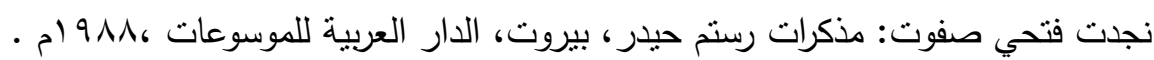


تخريج اجيال عر اقية مؤهلة وقادرة على تحمل المسوؤلية وبناء الوطن.

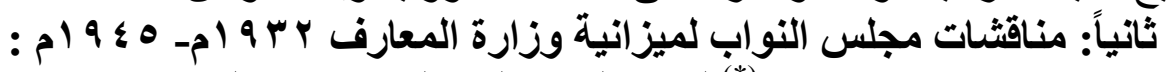

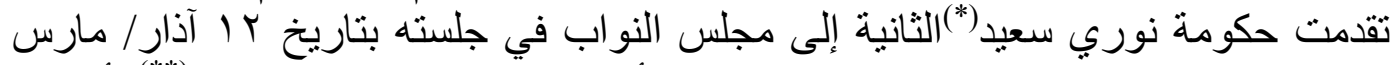

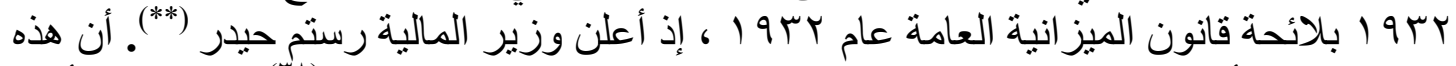

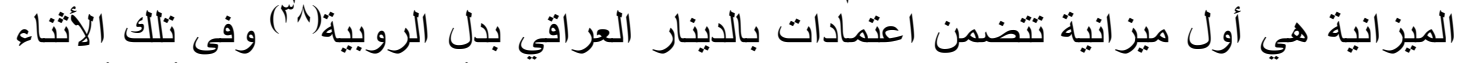

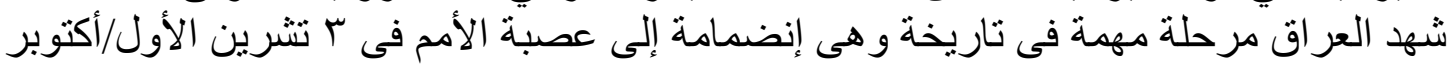

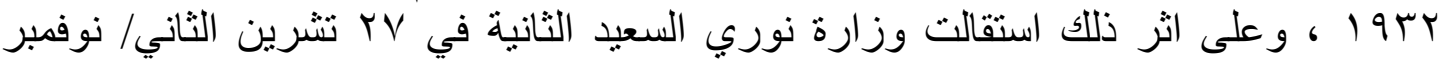

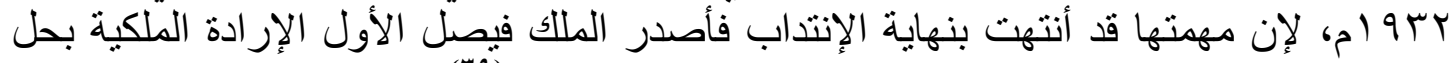

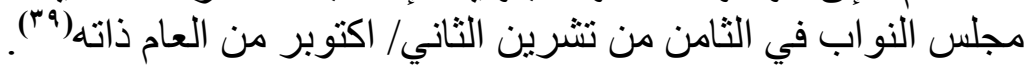

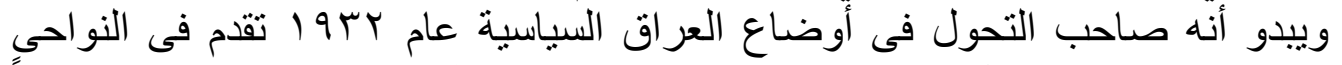

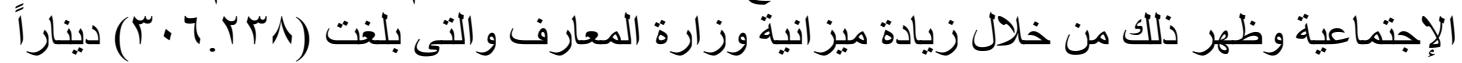

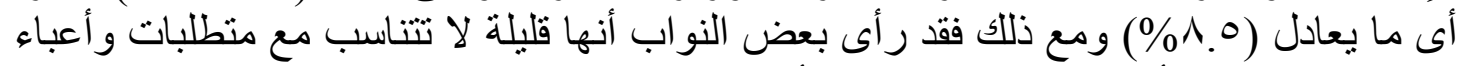

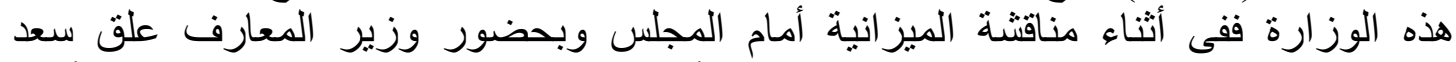

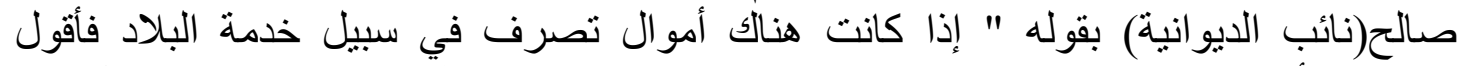

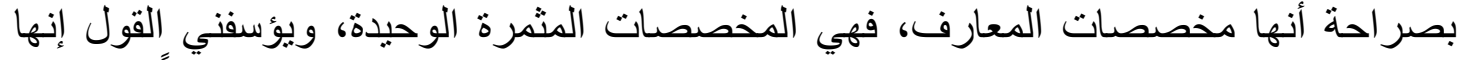

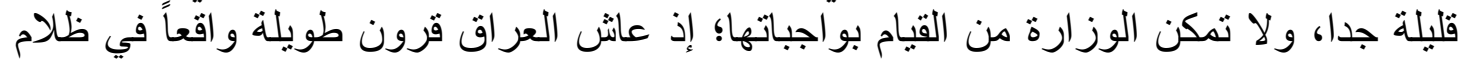

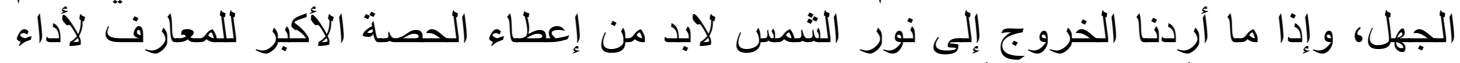
دور ها المقس، وأن لا يستكثر أحد على المعارف زئاد زيادة مخصصاتها.

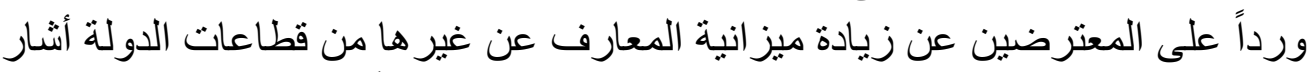

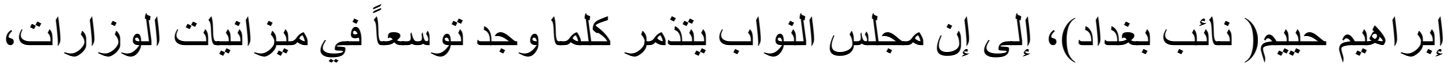

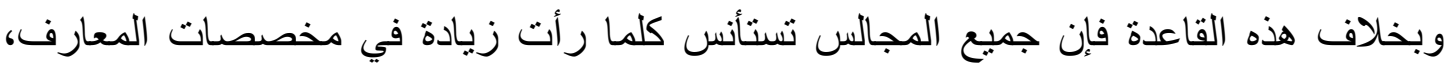

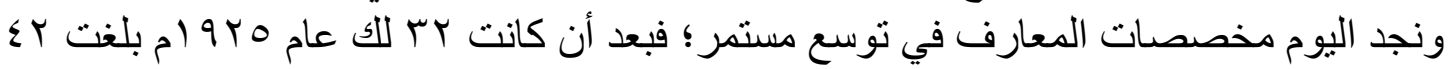

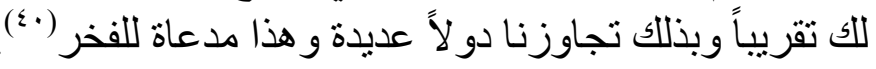

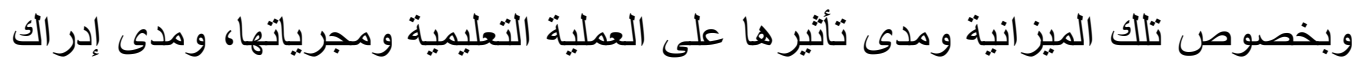

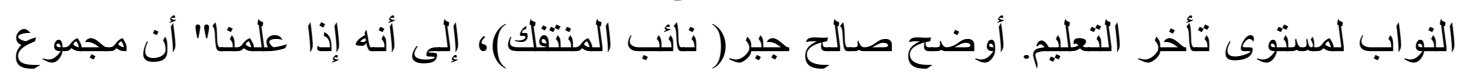

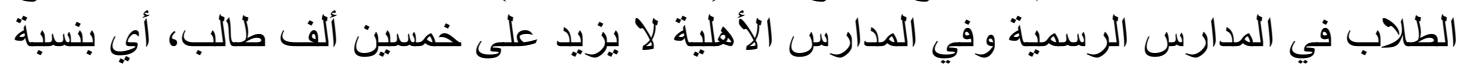

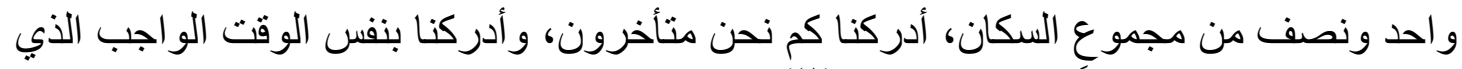

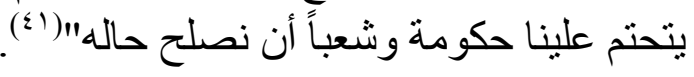
رغم الزيادة التى طر أت على ميزانية المعارف مع تطور أوضاع العراق السياسية إلا أن

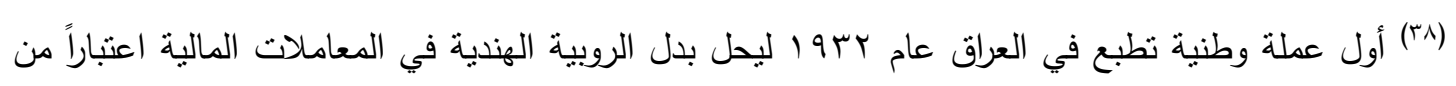

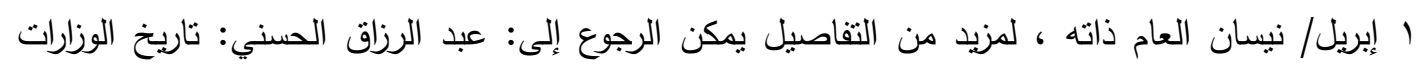

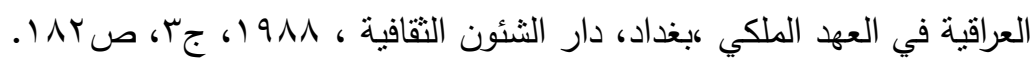

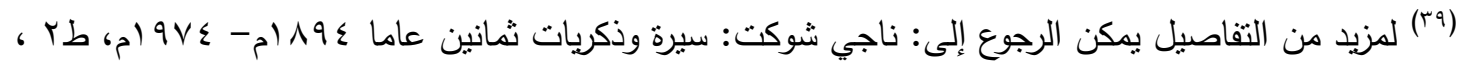

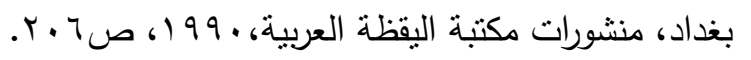

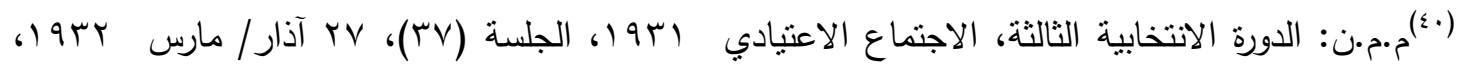

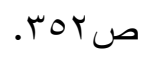

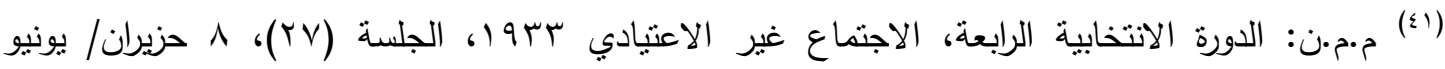

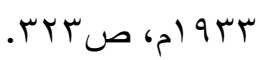




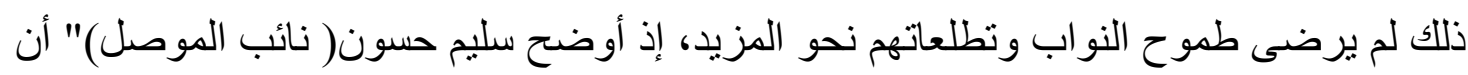

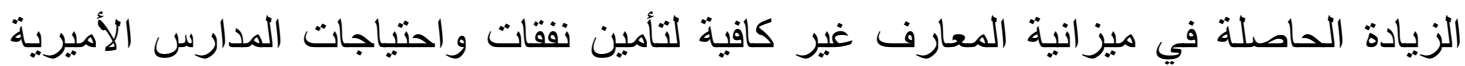

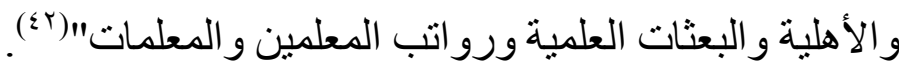

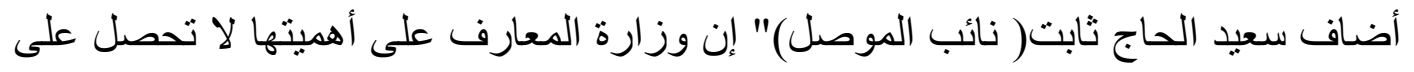

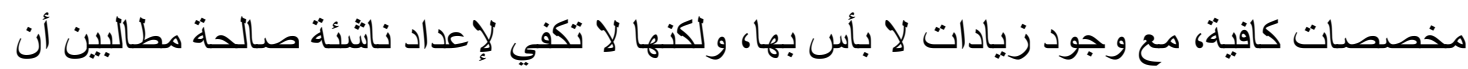

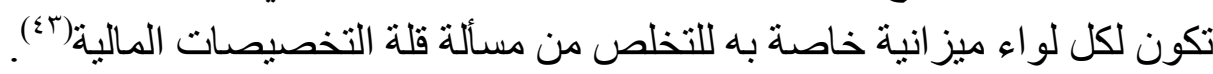

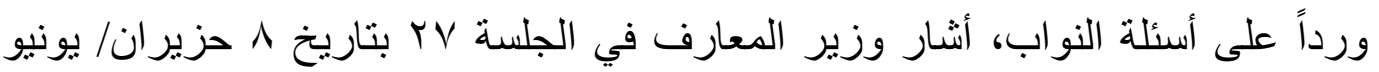

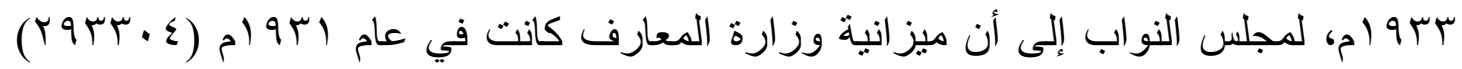

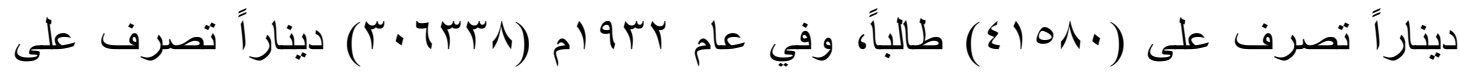

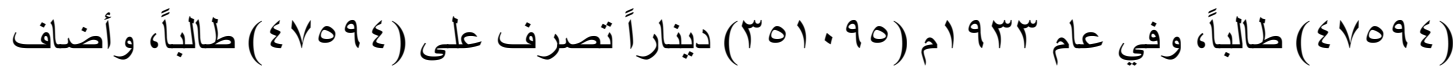

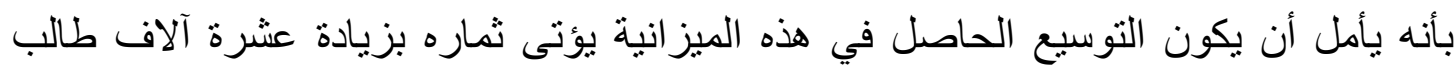
علاوة على هذا العدد".

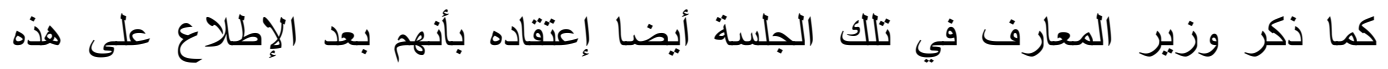

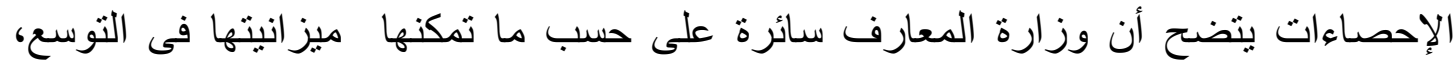

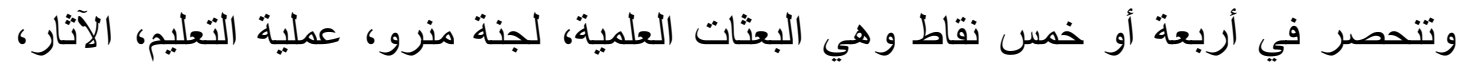
الإمتحانات التى سيتم الإنفاق عليها. و على العكس من ذللك فقد انتقد علي محمود( نائب الكوت)، مخصصات فئات وزارة

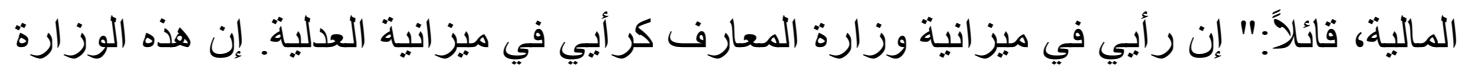

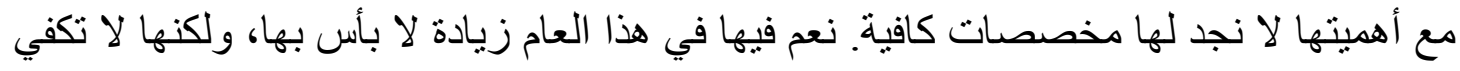

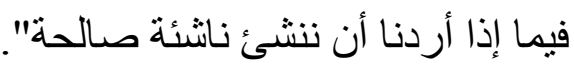

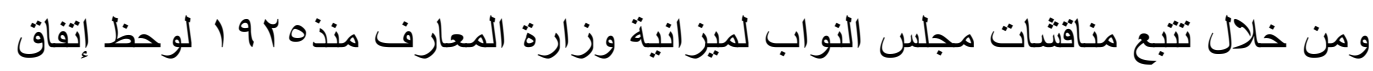

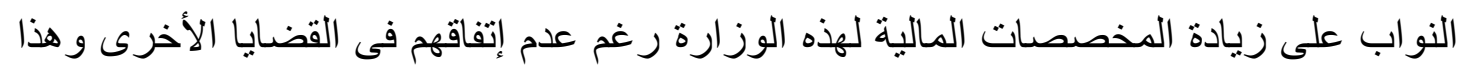

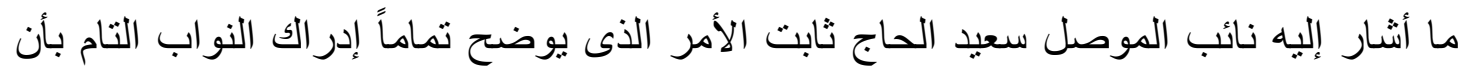
التعليم هو من أهم الأسس لبناء العراق الحديث.

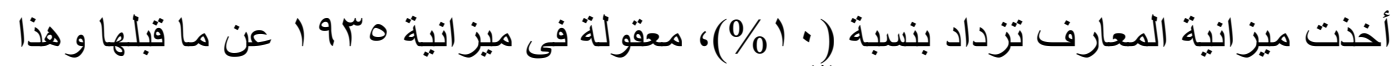

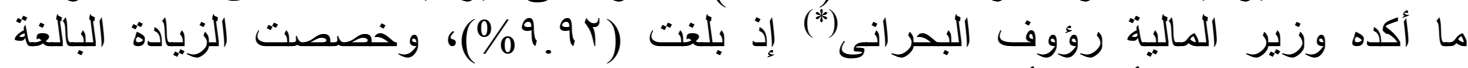

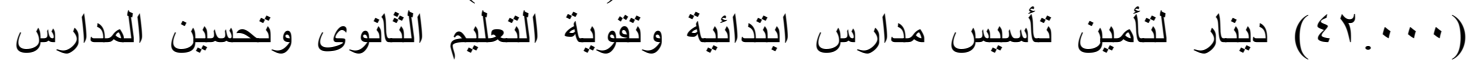

(r) م.م.ن: الدورة الانتخابية الرابعة، الاجتماع غير الاعتيادي سبوا، الجلسة (rr)، r حزيران/ يونيو

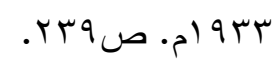

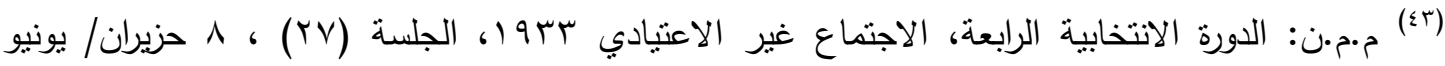

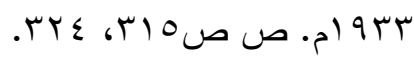


الصناعية:( «)

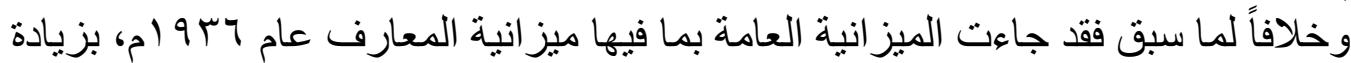

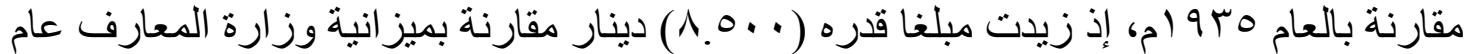

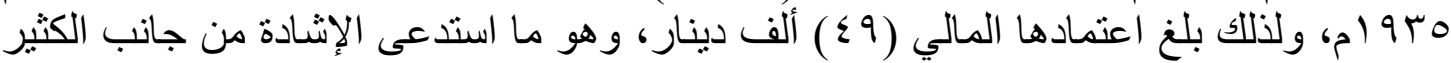

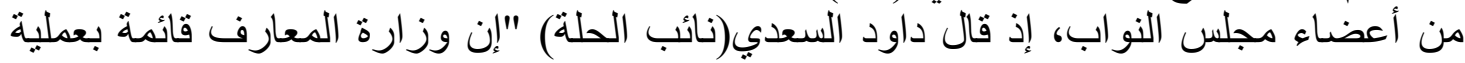

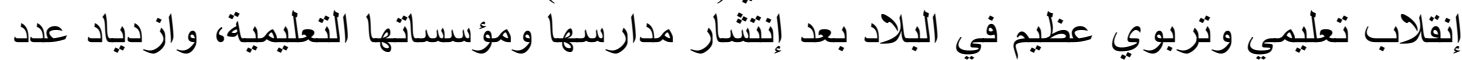

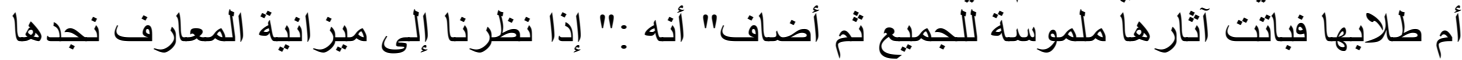

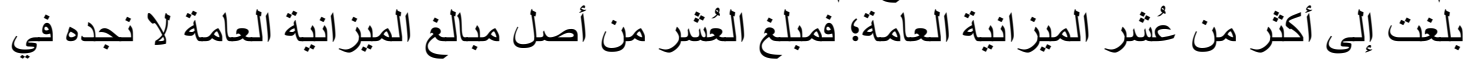

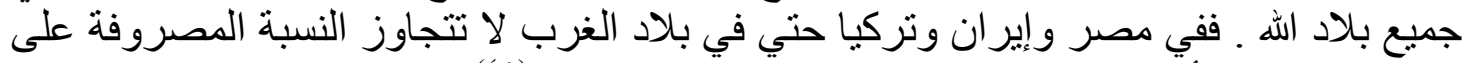

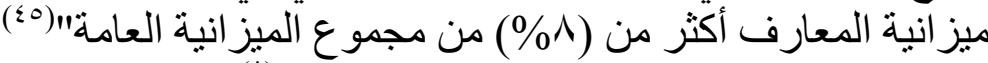

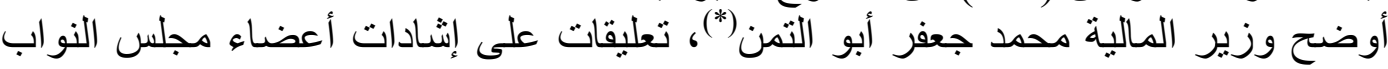

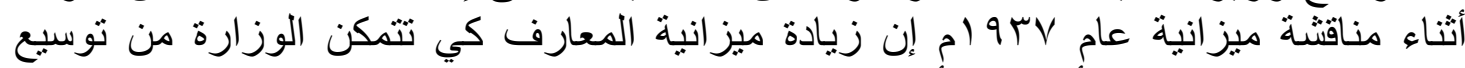

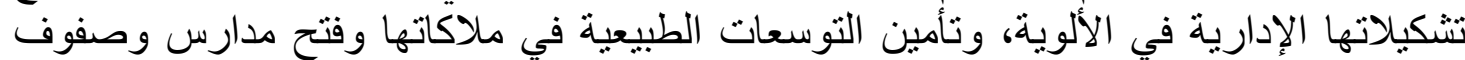

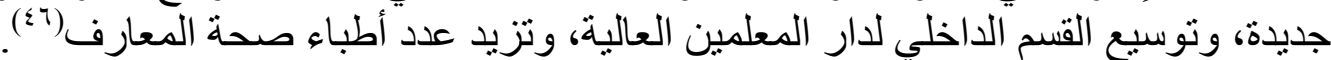

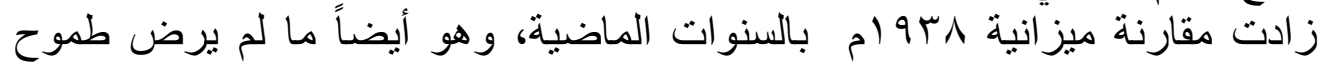

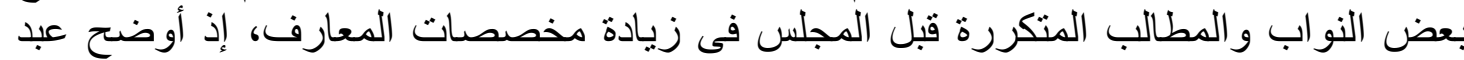

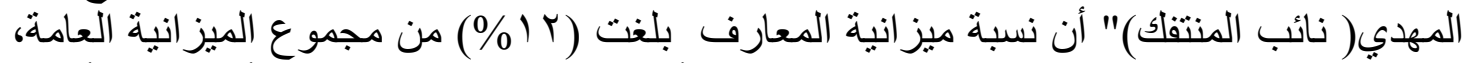

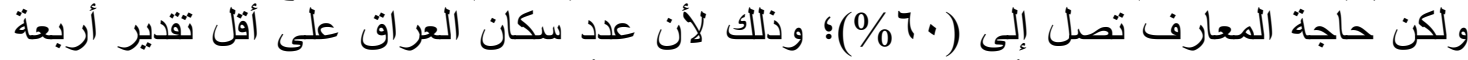

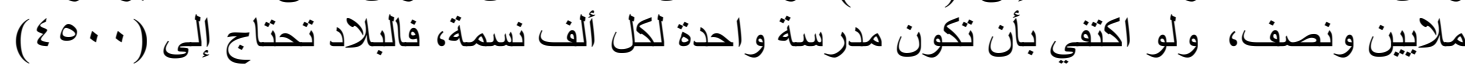

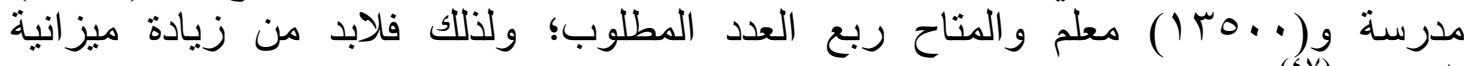

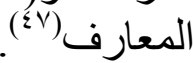

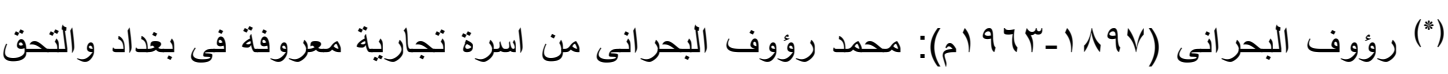

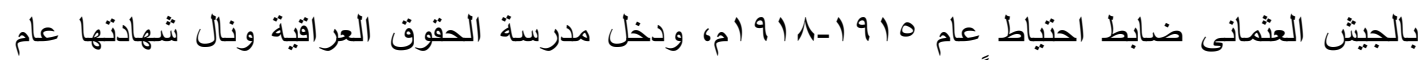

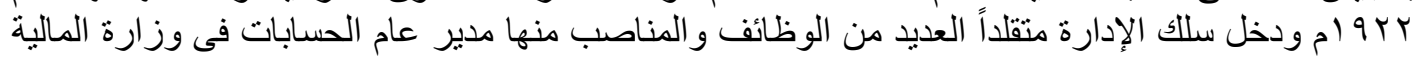

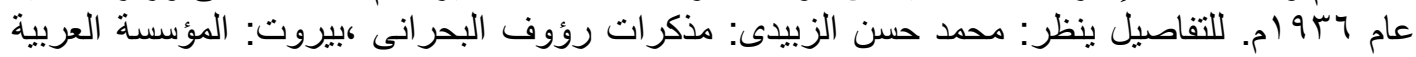

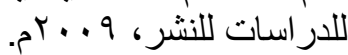

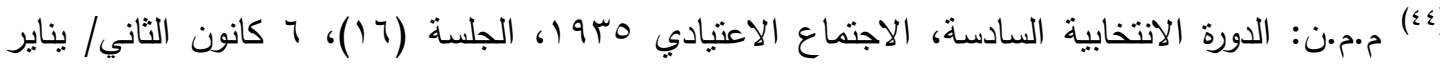

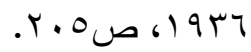

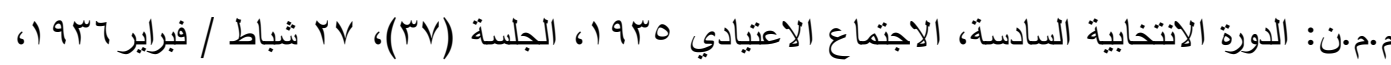
$(\leqslant 0)$

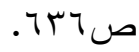
(")محد جعفر أبو التمن (1101 (م- 19 (م)): محمد جعفر جلبي ابو التمن، من بغداد، من فئة التجار، ذو

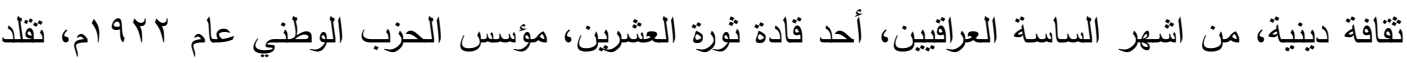

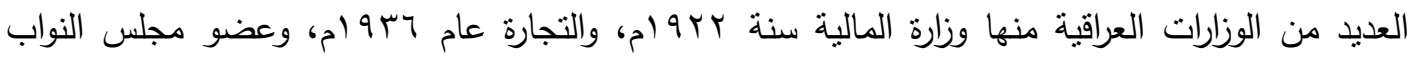

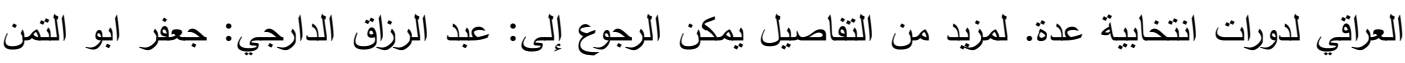

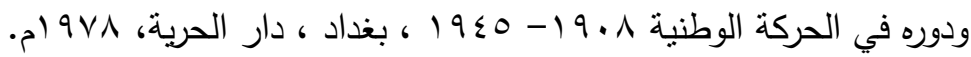

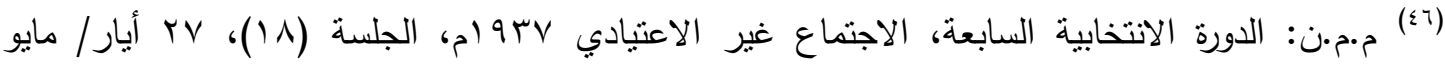
TrE

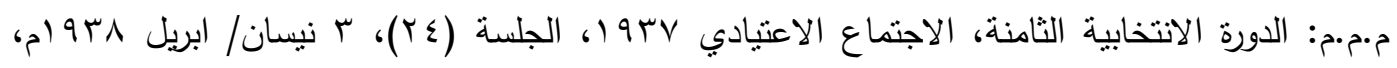
$(\varepsilon v)$ 


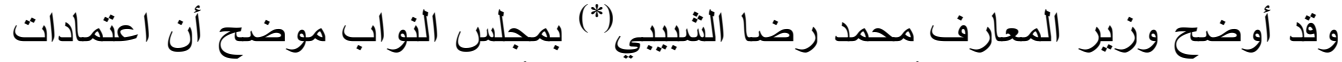

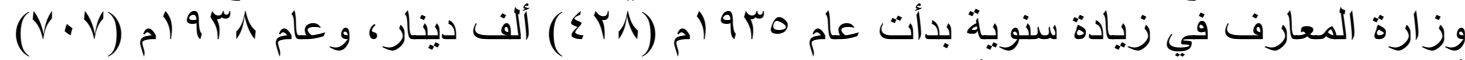

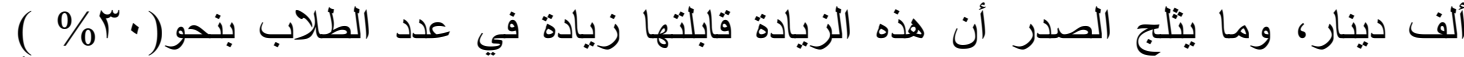

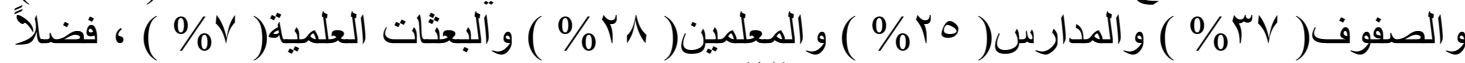

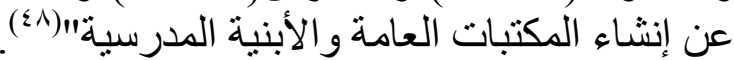

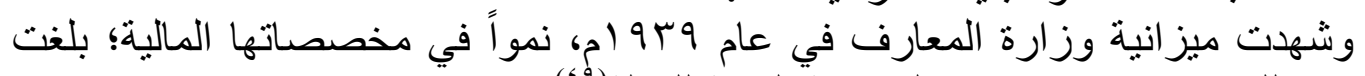

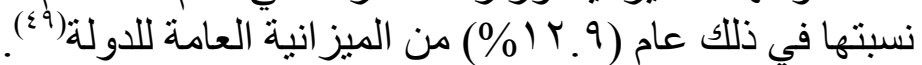

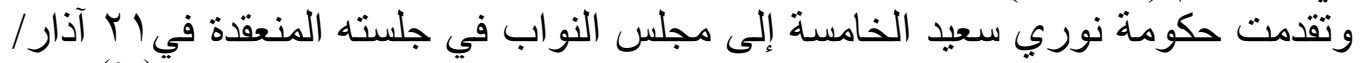

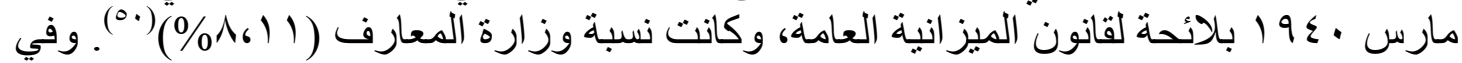

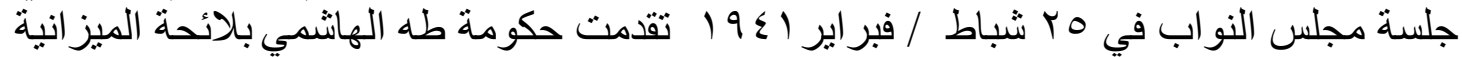

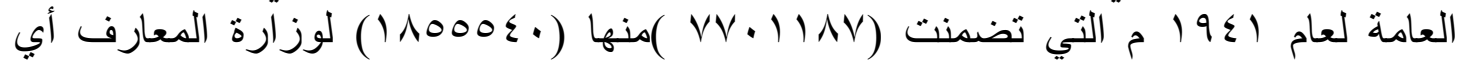

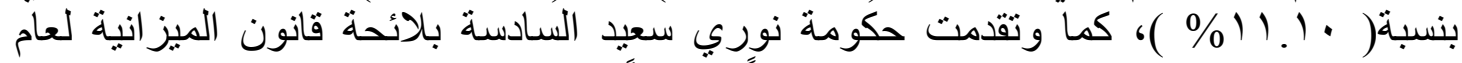

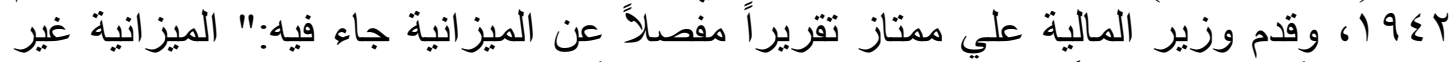

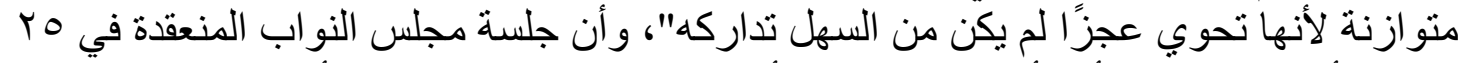

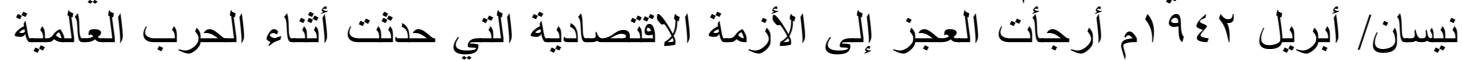

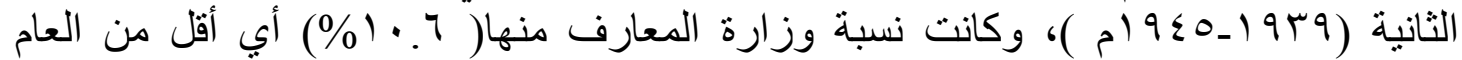

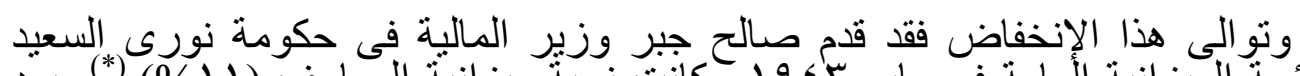

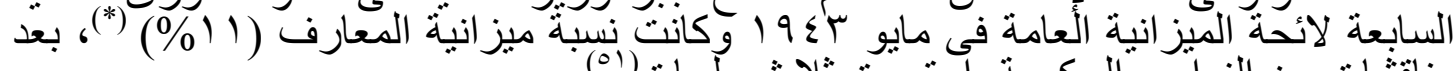

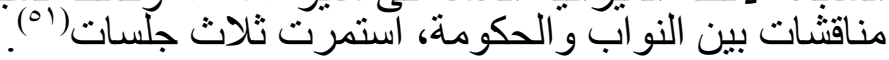

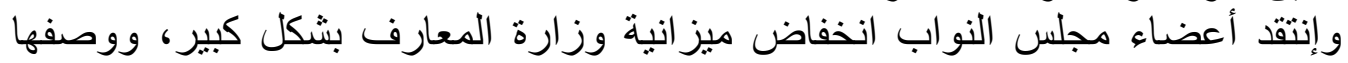

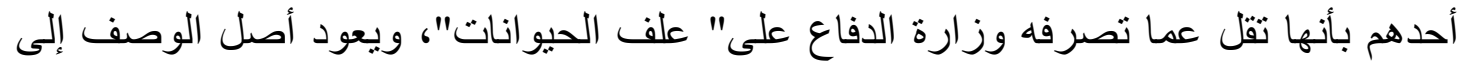

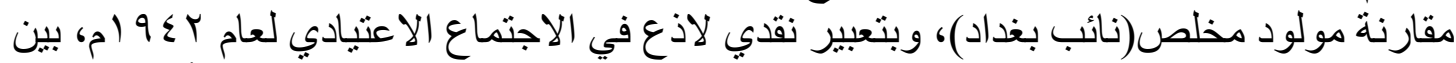

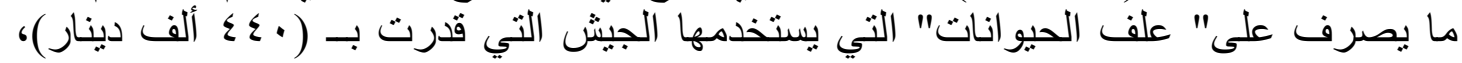

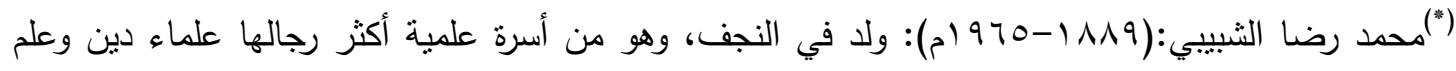

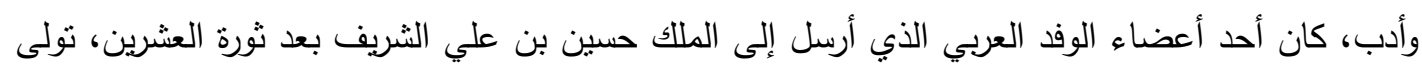
منصب وزير المعارف عدة مرات، وكان عضو في مجلس النواب في أكثر من دورة انتخابية. لمزيد من

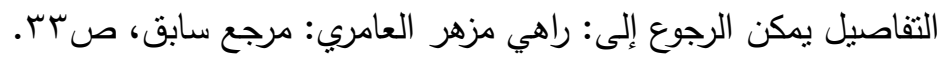

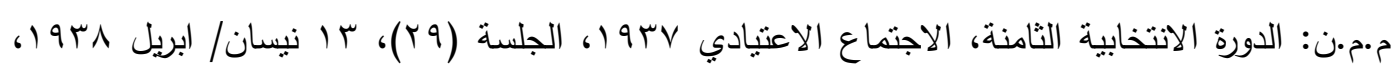
(₹八) صשrVז.

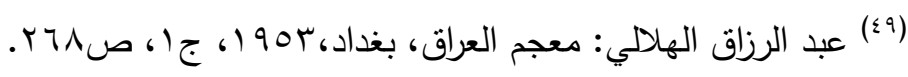

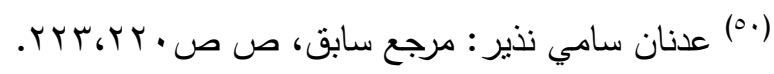
(") صالح جبر (190-190V-190) ولد في مدينة الناصرية واكمل الثانوية في بغداد، رجل حقوقي وسياسي واداري عراقي

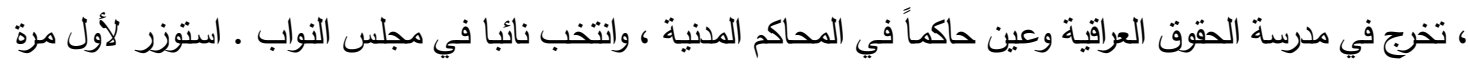

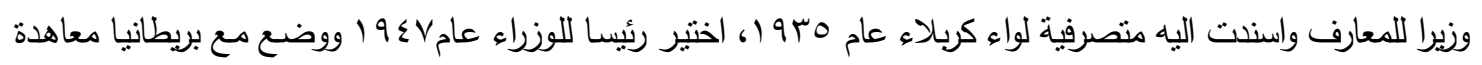

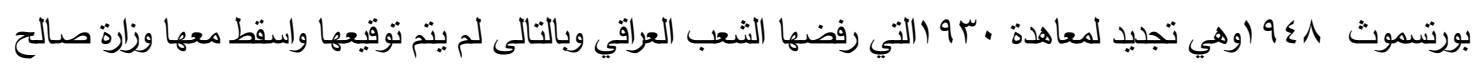

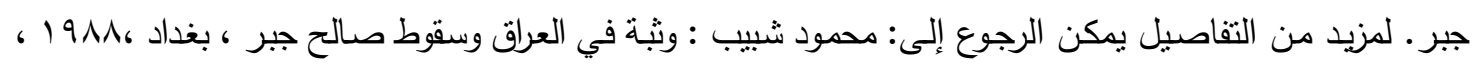


يضاف إليها المبلغ نفسه لمداواتها، في الوقت الذي لا يعدو جميع ما يصرف على "المدارس

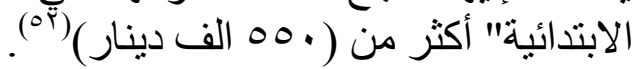

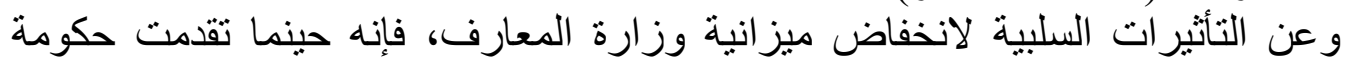

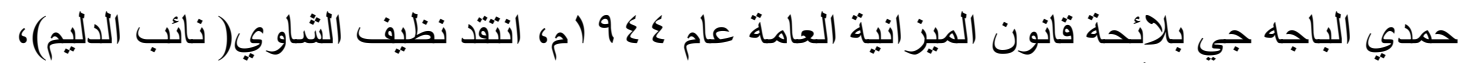

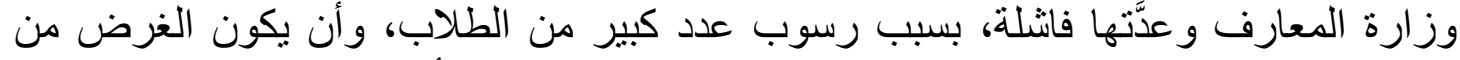

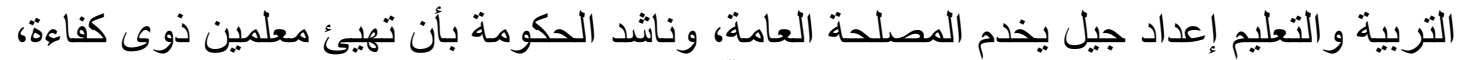

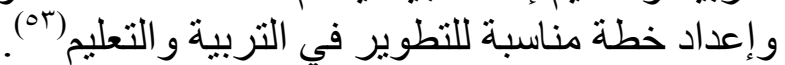

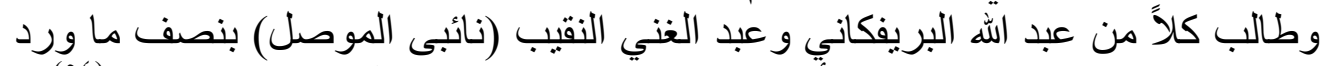

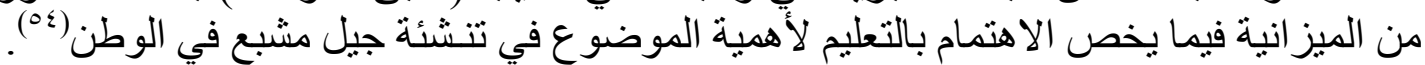

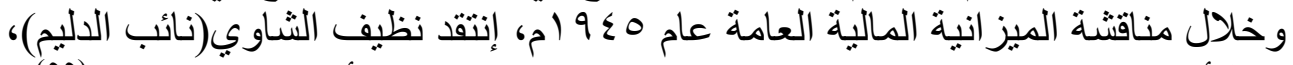

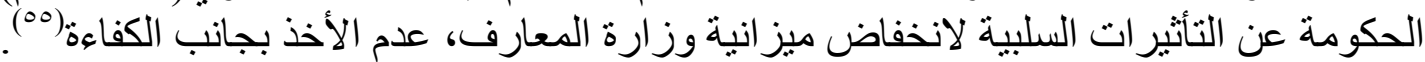

ويوضتح الجدول الآتى ميزانية وزارة المعارف بالدينار العر اقى خلال المدة من ( بـو ا ـ

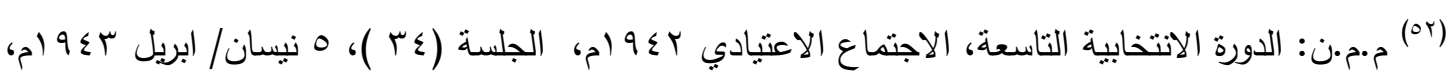

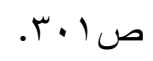

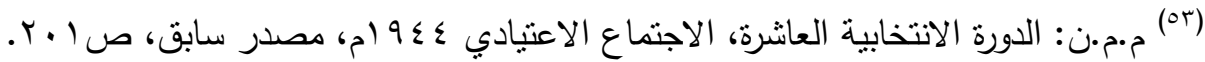

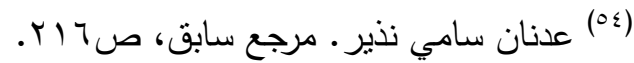

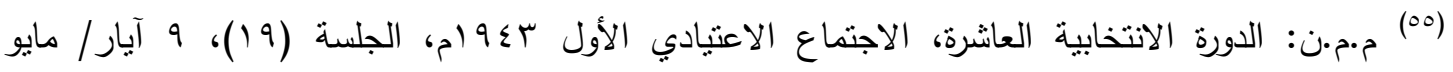


$:^{(07)}($ a) $9 \leq 0$

\begin{tabular}{|c|c|c|c|}
\hline النسبة المئوية & المعارف مبز انية & الميز انية العامة & السنة المالية \\
\hline$\% \wedge .0$ & T.TrM & rov. $\varepsilon \leqslant r$ & r |م-سوس ام \\
\hline$\%$ & ro1.90 & rV $1 \leqslant q . \varepsilon$ & 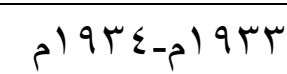 \\
\hline$\%) \cdot . r$ & r^९q 17 & rNITI9V & 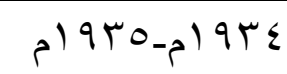 \\
\hline$\% 9.7$ & हाוq . & $\leqslant \leqslant 9 \leqslant \leqslant 97$ & ه山ه |م-4س (م \\
\hline$\% 1 \cdot .0$ & $\leq 9 \leq r \wedge \leq$ & EVTVTRO & דr \\
\hline$\% \backslash r . \mid$ & צYォIT. & $0179 \varepsilon \cdot r$ & 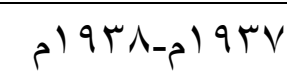 \\
\hline$\%)$ r.q & $V \cdot 107$ & $0 \leq 7911 \%$ & 人 \\
\hline$\%) Y_{6} V$ & $\Lambda) \cdot \Sigma V V$ & & 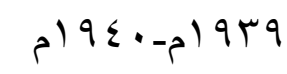 \\
\hline $0 / 11$ ، & $\Lambda \leqslant \Lambda) \neg \Lambda$ & $V) \leq \varepsilon q 1$. & م) $9 \leq 1$ م 9 . \\
\hline$\% 1161$ & $1000 \leqslant$. & $V V \cdot 111 \mathrm{~V}$ & م) $9 \leq r_{-p} \mid 9 \leq 1$ \\
\hline$\% 1 \cdot .70$ & $|1 \pi| \varepsilon \mid \varepsilon$ & I.TY.AYT & | $9 \leqslant r-م \mid 9 \leqslant Y$ \\
\hline$\% \backslash 1$ & $10100 \leqslant Y$ & $|r V \leqslant q \mu r|$ & م) $9 \leq \leqslant-$ م) $9 \leq r$ \\
\hline$\% \wedge_{6} 9$ & & $10 \leqslant \Lambda \leqslant V O r$ & م) $9 \leq 0-$ م) $9 \leq \leqslant$ \\
\hline
\end{tabular}

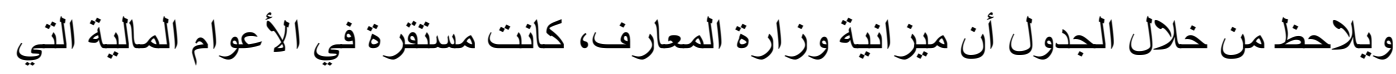

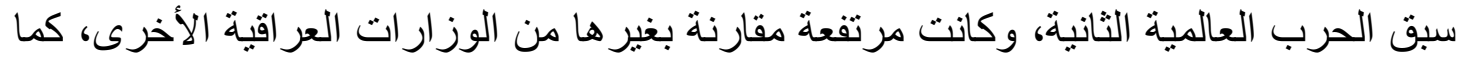

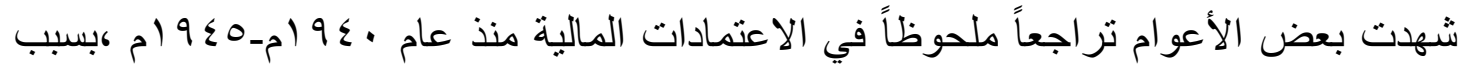

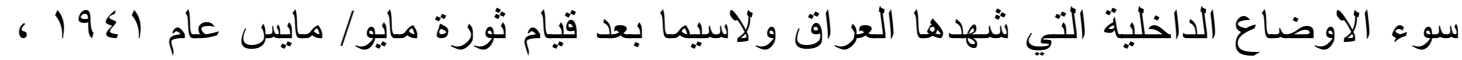

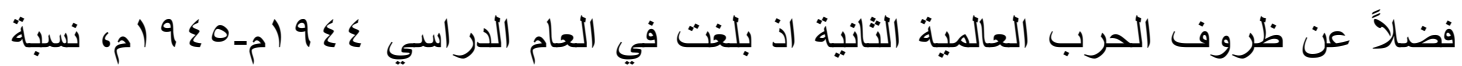

(1) المزيد من التفاصيل يمكن الرجوع إلى: الحكومة العراقية: وزارة التخطبط، التقرير السنوي عن سير التربية والتعليم لعام 90 1ام- 901 ام بغداد: مطبعة الحكومة، 909 ام، صعء ؛ الحكومة العراقية: وزارة المالية،

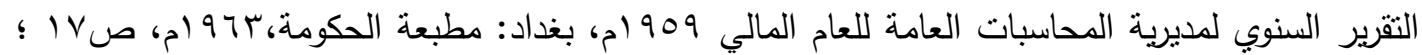

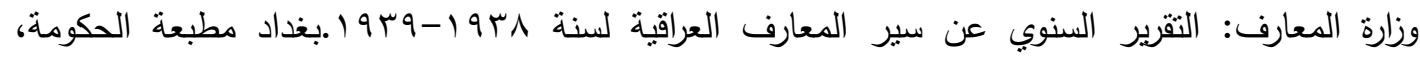

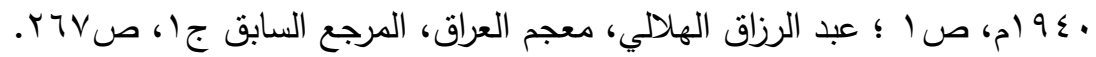




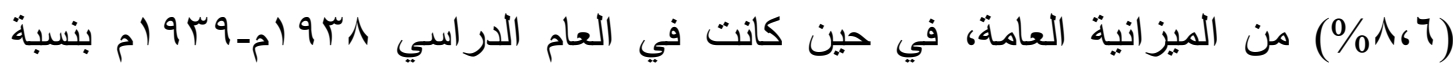

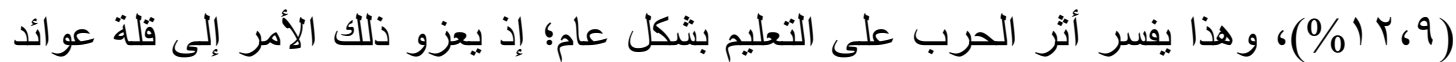
العر اق النفطية، بسبب تحكم الثركات الأجنبية الاحتكارية في إنتاج النفط العر اقئ لئي.

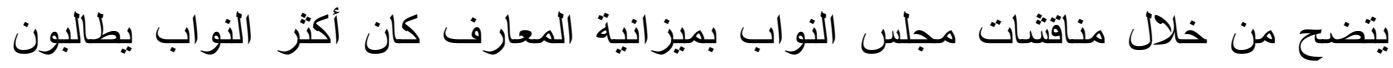
بالزيادة لإعتمادات لوزارة المعارف ومتفقين على تلك الزيادة ويهتمون بالمعارف لكونها البنية

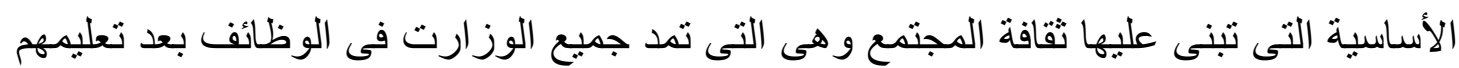


توصل البحث الى جملة من النتائج:-

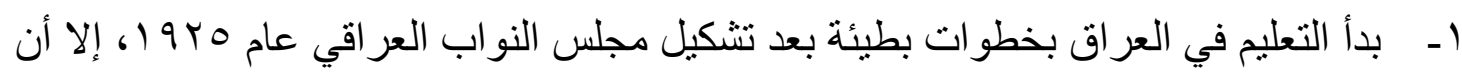
المنافنتات ومداخلات النواب أثنرت عبر جلسات متنوعة للمجلس في الضغط على مسؤولي وزارة المعارف سواء بحضور المسؤولين إلى مجلس النواب، او حتي تواصل النواب مع الملك فيصل الأول من اجل تطوير العملية التعليمة. r - أصبحت مطالبات النواب الصريحة بشأن زيادة نفقات التعليم الثغل الشـاغل لعدد كبير منهم وفق اعتبار انه حق شرعي ووطني لجميع العر اقيين ـ إذ طالب النواب في كل جلسة خاصة

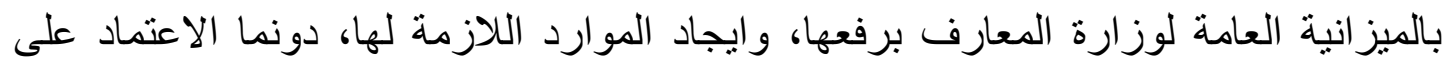

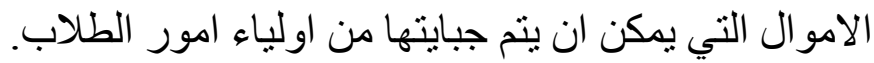
r- أجبر مجلس النواب العراقي رؤساء الوزراء المتعاقبين على تخصيص نسبة كبيرة من

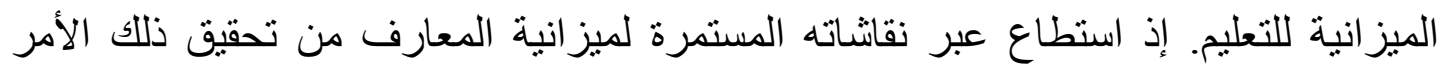
ويعبر ذلك عن حس وطني لدى النو اب باهمية التعليم ودوره في رفع المجتمع الى مصاف الدول

ع- خصصت المبالغ لتطوير كفاءات المعلمين و المدرسين، وزيادة نفقات بناء المدارس، وطبع الكتب، وارسال بعثات طلابية خارج العراق وتطوير المعاهد وانشاء الكليات، ازدياد إقبال

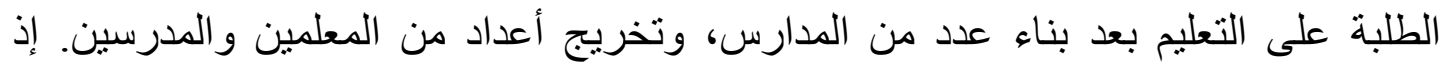

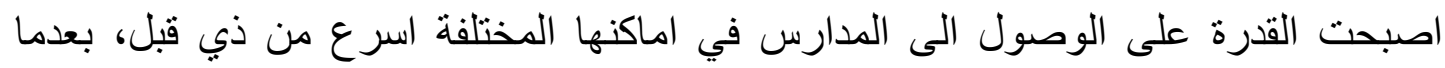
تو افرت كافة السبل في تحقيق ذلك، جرى فتح عدد من الكليات و المعاهد، وخصصت لها مبالغ

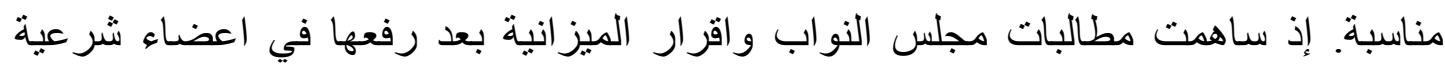
قانونية و إلز امية لإنفاق تللك الميز انية فيما وضعت لله، ان مطالبات مجلس النو اب العر اقي لزيادة النفقات المالية على التعليم جاء من حرص النواب على خلق جيل جديد واعي ـ وربما يعود ذللك في جزء كبير منه من الخلفيات التعليمية والثقافية للنواب، والتي كانت دوما دافعا لهم نحو جئ المطالبة بتحسين حالة التعليم في البلاد.

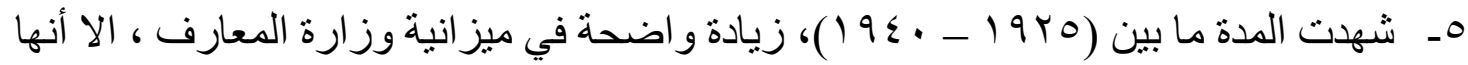

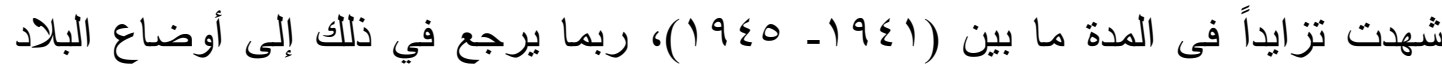

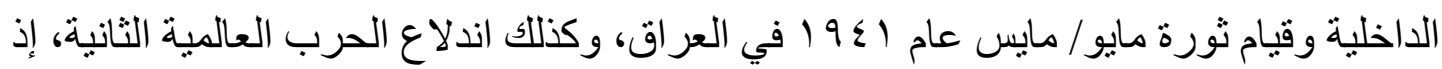

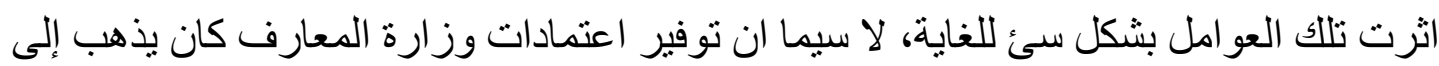

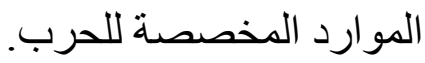




$$
\begin{aligned}
& \text { قائمة المصادر والمراجع }
\end{aligned}
$$

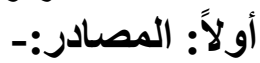

$$
\begin{aligned}
& \text { ا ـ الوثائق العربية غير المنشورة }
\end{aligned}
$$

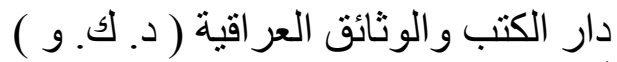

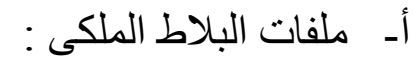

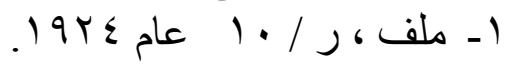

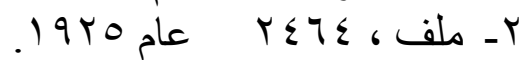

$$
\begin{aligned}
& \text { محاضر مجلس النواب: } \\
& \text { الإجتماع للأعوام ، } \\
& -1949-19 r V-19 r 0-19 r \varepsilon-19 \mu r-19 r r-19 r 1 \\
& .19 \leq \varepsilon-19 \leq r-19 \leq r \\
& \text { أـ باللغة العربية } \\
& \text { r- المنشورة }
\end{aligned}
$$

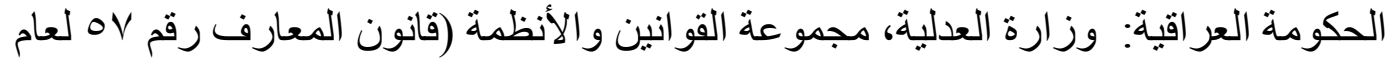

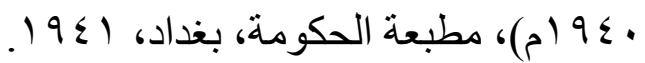

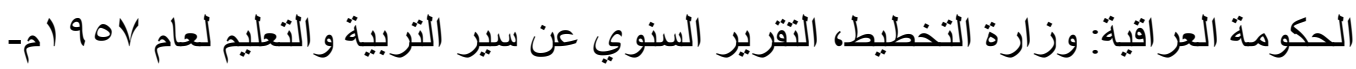

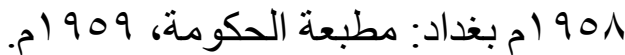
الحكومة العر اقية: وز ارة المالية، التقرير السنوي لمديرية المحاسبات العامة للعام المالي 909 (م،

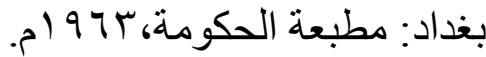

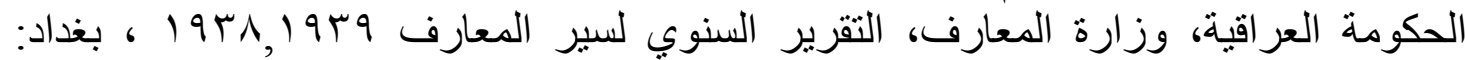

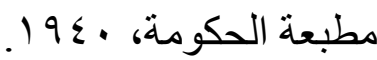
الحكومة العر اقية، وزارة المعارف ، التقرير السنوي عن لسير المعارف للسنوات

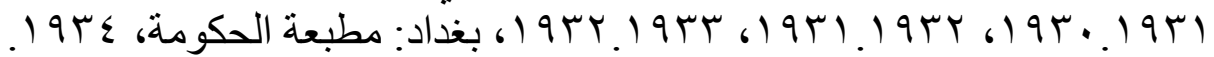

\section{ثانياً: رسائل جامعية غير منشورة}

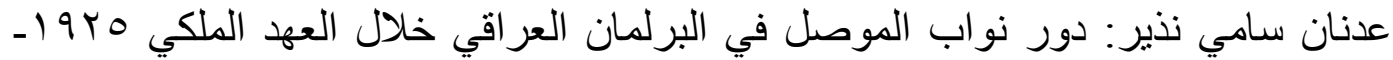

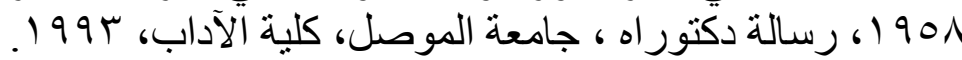

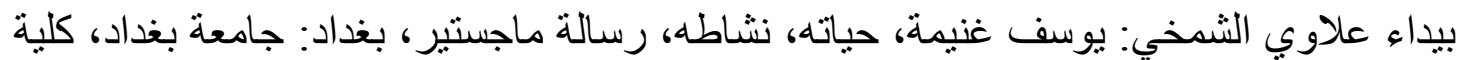

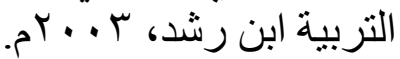

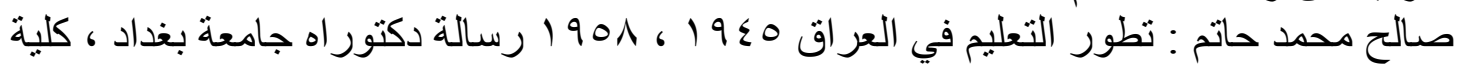

$$
\text { ثالثاً:- الاوريات (صحف ومجلات) }
$$

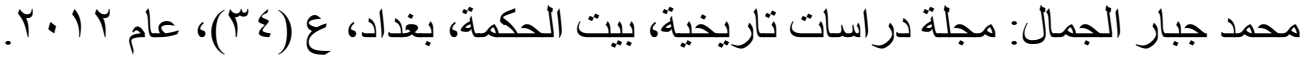

$$
\text { صحف: محمد جار: }
$$

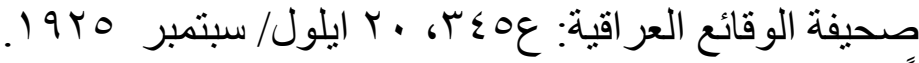

$$
\text { رابعاً:- المراجع }
$$

المر اجع العربية 


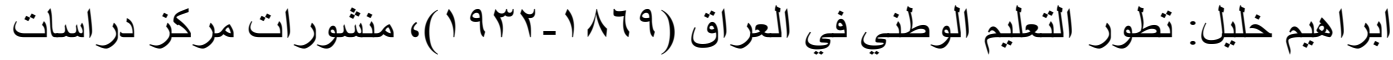

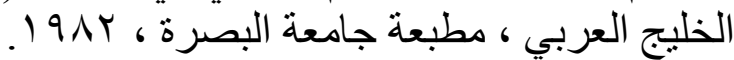

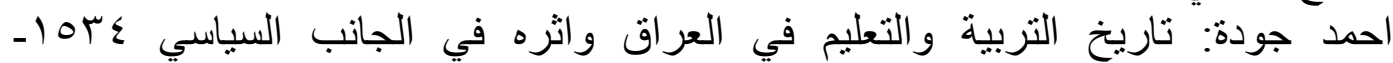

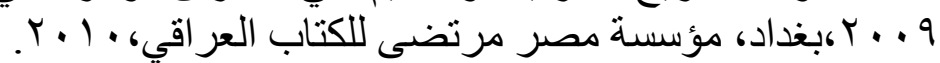

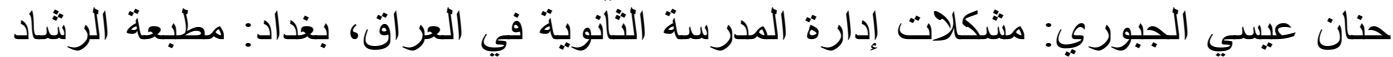
م $9 \mathrm{~V}$.

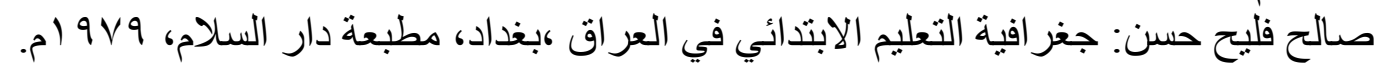

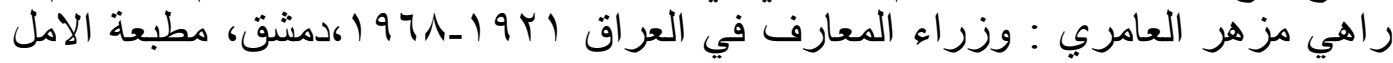

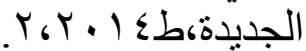
سعاد رؤوف شير محكمد : نوري السعيد ودوره في السياسة العر اقية حتى عام 0 ـو (، بغداد

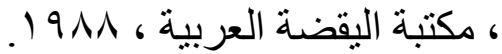
شاكر الأمين: تطور التربية والتعليم في العراق، محاضرات اتهية غير مطبو عة، بغداد: الجامعة

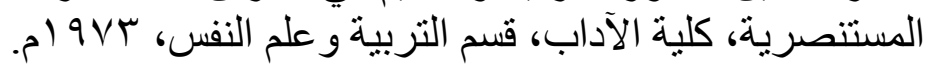
عباس العزاوي: تاريخ النقود العراقية لما بعد العهود العباسية ، بغداد، شركة شركة التجارة

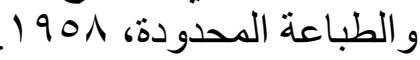
عبد الرزاق الحسني: تاريخ الوزارات العراقية في العهد الملكي ، بغداد: دار الثئون التقافة

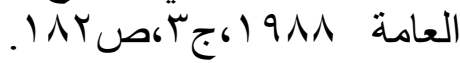

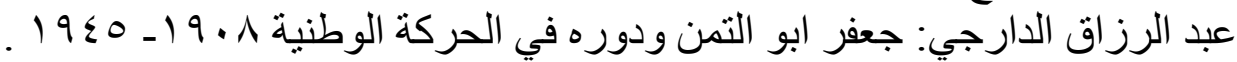

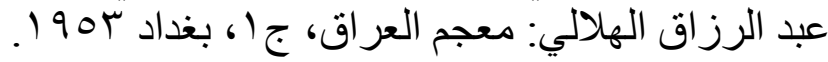

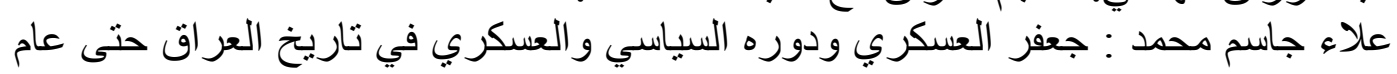

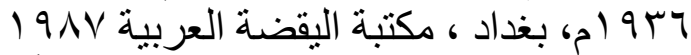

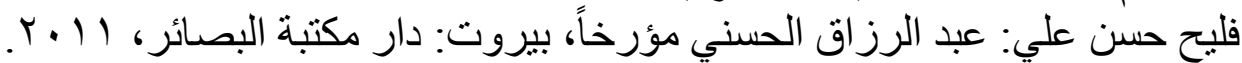

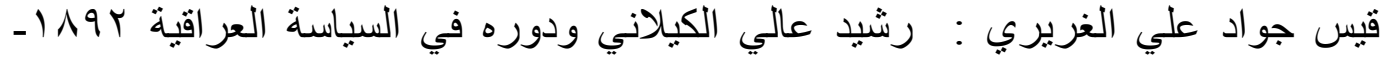

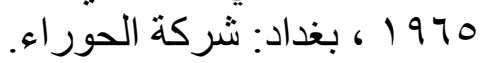

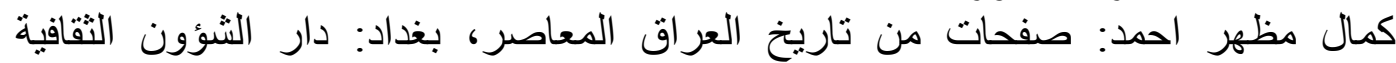

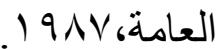
محب الدين الخطيب ، جعفر العسكري ، موجز حياته وصدى مصر عه في الثرق والغرب ، القاهرة ، المطبعة السلفية. محمد حسن الزبيدي: مذكرات رؤوف البحراني، بيروت: المؤسسة العربية للار اسات محمود رزوق الحمد: الحركة الكردية في العراق، دور البرزانيين في طريق الحكم الذاتي

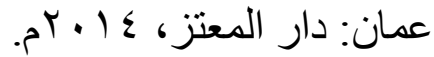

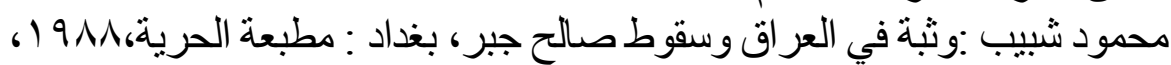

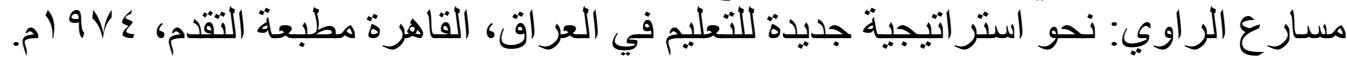

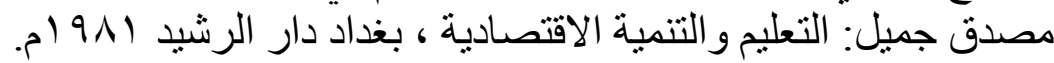

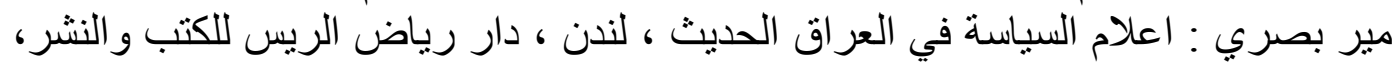

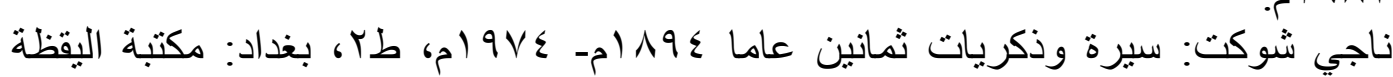
العربية، • 99 (م.

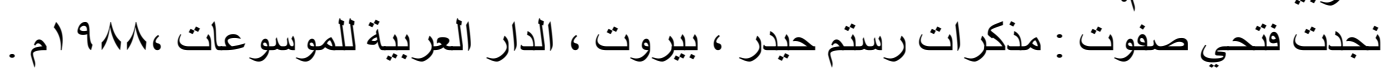




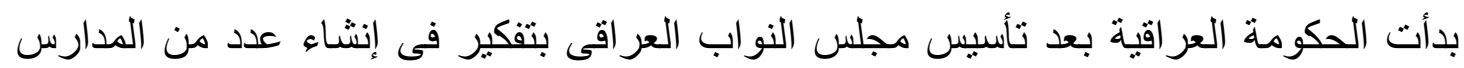

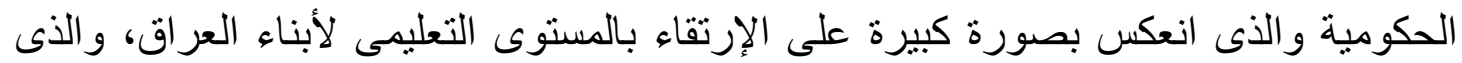

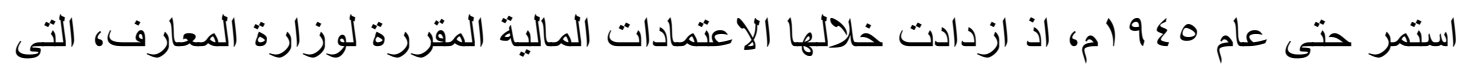

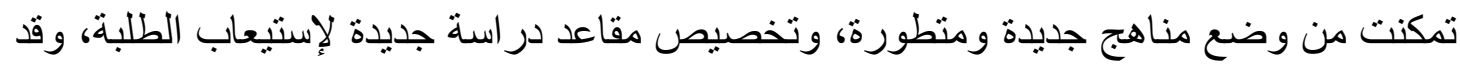

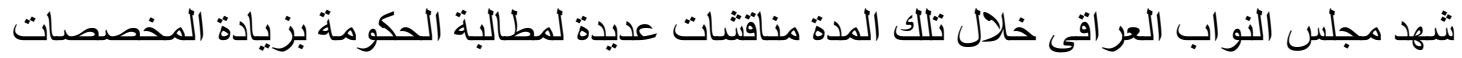

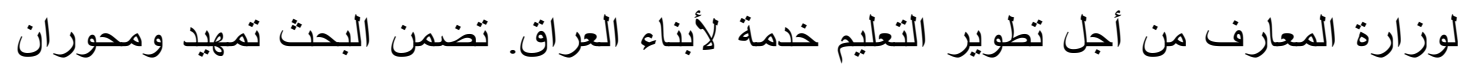

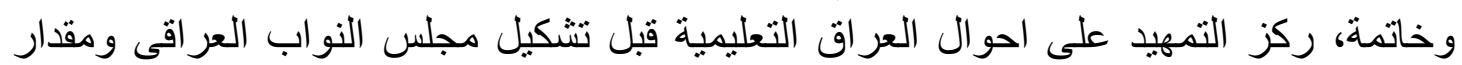

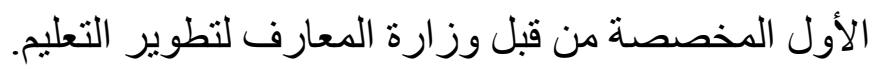

فى حين شكل المحور الاول: مناقثات مجلس النواب بشأن رفع مستوى التعليم والميزانية

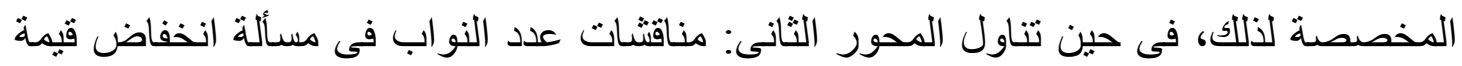

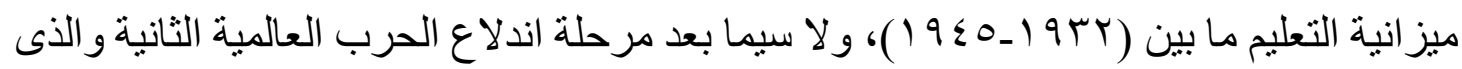
انعكس بصورة فعلية على الاقتصاد العر اقى.

$$
\text { توصل البحث الى جملة من النتائج، وهى على النحو الاتى: }
$$

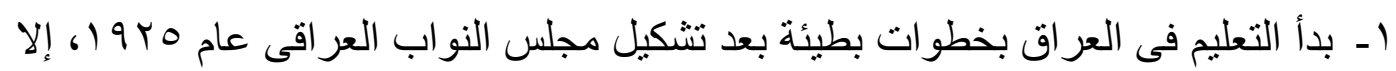

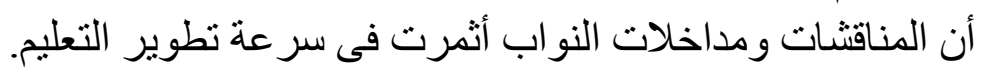

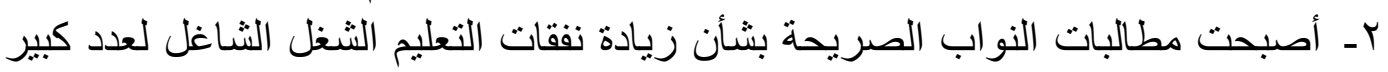
من النواب وفق اعتبار انه حق شرعى ووطنى لجميع العر اقيين. 


\begin{abstract}
:
The Iraqi government began after the establishment of the Iraqi Council of Representatives To consider the establishment of a number of public schools, which was reflected significantly on the upgrading of the educational level of the people of Iraq, which lasted until 1945, As the financial allocations to the Ministry of Education increased, Which has been able to develop new and sophisticated curricula, And the allocation of new seats to accommodate students, The Iraqi Council of Representatives witnessed during that period Numerous discussions to demand the government to increase allocations to the Ministry of Education in order to develop the education service for the people of Iraq. Search included an Preface, Two axes and a conclusion, The preface center On Iraq's educational conditions Before the formation of the Iraqi Council of Representatives And the amount of funds allocated by the Ministry of Education for the development of education.

The first axis: discussions Council of Representatives Raising the level of education and budget allocated, The second axis:

Discussions of a number of deputies In the issue of the low value of the education budget between (1932 - 1945), especially after the stage Second World war Which reflected effectively on the Iraqi economy.

Search got to a number of results, which are as follows:

1 - Education in Iraq began slow steps after the formation of the Iraqi Council of Representatives in 1925, but the discussions and interventions of the deputies resulted in the rapid development of education.
\end{abstract}


2 - The demands of the deputies on the explicit increase in education expenses occupy the concern of a large number of deputies as a legitimate right and national for all Iraqis. 